\title{
Water scarcity and oil palm expansion: social views and environmental processes
}

\author{
Jennifer Merten $^{1}$, Alexander Röll ${ }^{2}$, Thomas Guillaume $^{3}$, Ana Meijide $^{4}$, Suria Tarigan $^{5}$, Herdhata Agusta $^{6}$, Claudia Dislich $^{7}$, \\ Christoph Dittrich $^{1}, \underline{\text { Heiko Faust }}^{1}$, Dodo Gunawan $^{8}$, Jonas Hein $^{9}$, Hendravanto $^{10}$, Alexander Knohl $^{4}$, Yakov Kuzyakov $^{3}, \underline{\text { Kerstin }}^{2}$ \\ Wiegand $^{7}$ and Dirk Hölscher ${ }^{2}$
}

\begin{abstract}
Conversions of natural ecosystems, e.g., from rain forests to managed plantations, result in significant changes in the hydrological cycle including periodic water scarcity. In Indonesia, large areas of forest were lost and extensive oil palm plantations were established over the last decades. We conducted a combined social and environmental study in a region of recent land-use change, the Jambi Province on Sumatra. The objective was to derive complementary lines of arguments to provide balanced insights into environmental perceptions and eco-hydrological processes accompanying land-use change. Interviews with villagers highlighted concerns regarding decreasing water levels in wells during dry periods and increasing fluctuations in stream flow between rainy and dry periods. Periodic water scarcity was found to severely impact livelihoods, which increased social polarization. Sap flux measurements on forest trees and oil palms indicate that oil palm plantations use as much water as forests for transpiration. Eddy covariance analyses of evapotranspiration over oil palm point to substantial additional sources of evaporation in oil palm plantations such as the soil and epiphytes. Stream base flow from a catchment dominated by oil palms was lower than from a catchment dominated by rubber plantations; both showed high peaks after rainfall. An estimate of erosion indicated approximately $30 \mathrm{~cm}$ of topsoil loss after forest conversion to both oil palm and rubber plantations. Analyses of climatic variables over the last 20 years and of a standardized precipitation evapotranspiration index for the last century suggested that droughts are recurrent in the area, but have not increased in frequency or intensity. Consequently, we assume that conversions of rain forest ecosystems to oil palm plantations lead to a redistribution of precipitated water by runoff, which leads to the reported periodic water scarcity. Our combined social and environmental approach points to significant and thus far neglected eco-hydrological consequences of oil palm expansion.
\end{abstract}

Key Words: eco-hydrology; environmental perception; erosion; evapotranspiration; forest; land-use change; runoff; rural water supply; streamflow; transpiration

\section{INTRODUCTION}

When there was still a lot of forest around Bungku even during a drought of two months we still had water in our wells. But now there is no forest anymore, there is oil palm. Farmer from Bungku, Jambi, Indonesia, June 2013.

Large-scale land-use change such as the current oil palm expansion in Indonesia is characterized by the interaction of social, economic, and ecological processes. It is increasingly recognized that such conversions require research that includes both human and environmental dimensions (Bradshaw and Bekoff 2001, Bodin and Tengö 2012, Moore et al. 2014, Ledford 2015). The integration of local knowledge and perceptions, e.g., the above statement by a farmer from Jambi (Sumatra, Indonesia) enables scientific research to directly address local people's concerns (Ostrom 2009, Pahl-Wostl et al. 2010, Scholz et al. 2011, as cited in Binder et al. 2013). Although the need for such problemdriven research has been emphasized in numerous studies, applied environmental research often fails to adequately integrate social analyses (Lele and Kurien 2011, Wandersee et al. 2012, Tàbara and Chabay 2013, Sagie et al. 2013, Reyers et al. 2013, Orenstein and Groner 2014). Thus, we see a need for applied interdisciplinary studies that give credit to the embeddedness of environmental processes in socio-cultural processes by confronting local environmental perceptions with natural science measurements.

Indonesia is currently undergoing large-scale land-use change characterized by declining areas of natural ecosystems and increasing areas of mono-culture plantations, thereby creating substantial changes in the social-ecological system. Particularly oil palm plantations have rapidly expanded in Indonesia over the past decades, from a total of less than one million ha in 1990 to over seven million ha in 2013; today, Indonesia is the global leader in crude palm oil production (FAO 2015). Oil palm often replaces other cash or subsistence crops, e.g., rubber plantations, but has also been identified as a driver of large-scale deforestation (Koh and Wilcove 2008, Carlson et al. 2012). Such large-scale forest conversion toward intensive agricultural systems may cause severe changes in the hydrological cycle (Bruijnzeel 1989, 2004, Krishnaswamy et al. 2013). In our study region, the Jambi province in Sumatra, the expansion of oil palm plantations has made water scarcity an issue in the human perception as, for example, expressed in the introductory quote. Such socio-

\footnotetext{
${ }^{1}$ Human Geography, Georg-August-Universität Göttingen, Germany, ${ }^{2}$ Tropical Silviculture and Forest Ecology, Georg-August-Universität Göttingen, Germany, ${ }^{3}$ Soil Science of Temperate Ecosystems, Georg-August-Universität Göttingen, Germany, ${ }^{4}$ Bioclimatology, Georg-AugustUniversität Göttingen, Germany, ${ }^{5}$ Soil and Natural Resources Management, Bogor Agricultural University, Indonesia, ${ }^{6}$ Agronomy and Horticulture, Bogor Agricultural University, Indonesia, ${ }^{7}$ Ecosystem Modelling, Georg-August-Universität Göttingen, Germany, ${ }^{8} \mathrm{Center}$ of Climate Change and Air Quality, Agency for Meteorology, Climatology and Geophysics, Jakarta, Indonesia, ${ }^{9}$ Department for Environmental Policy and Natural Resource Management, German Development Institute, Bonn, Germany, ${ }^{10}$ Forest Management Department, Faculty of Forestry, Bogor Agricultural University, Indonesia
} 
hydrological consequences and linkages of forest conversion have not yet been adequately studied (Lele 2009).

Available scientific as well as popular studies linking oil palm plantations to the water cycle mainly focus on water quality (e.g., Wakker 2005, Friends of the Earth et al. 2008, Babel et al. 2011, Colchester and Chao 2011, Buschmann et al. 2012, Gharibreza et al. 2013). The few social science studies examining water quantity do not explain the underlying reasons of the observed declines in water availability (e.g., Obidzinski et al. 2012, Larsen et al. 2014). From the natural sciences perspective, water-related studies on oil palm are scarce and often only examine single components of the hydrological cycle (also see Comte et al. 2012, Dislich et al. 2015).

In this study, we aim at integrating social and natural science approaches to analyze the social and eco-hydrological consequences of oil palm expansion. The starting point for our interdisciplinary, problem-oriented research is the environmental perception of changes in the water cycle by residents of Bungku, a village in Jambi. We investigate if and how these perceptions can be explained by empirically derived environmental variables that were measured in the vicinity of the mentioned village. For this purpose, we analyzed micrometeorological, eco-hydrological, and pedological measurements in oil palm plantations, rubber plantations, and forest sites. Unlike oil palm, rubber has been cultivated in Jambi since the first half of the 20th century (Feintrenie and Levang 2009). Rubber plantations today still represent the dominant land-use system in the province, extending over 660,000 ha in 2013 (BPS Jambi 2014). Our approach allows for an assessment of the environmental perceptions and ecohydrological processes following forest conversion to monoculture plantations. We also analyzed long-term climatic data to evaluate the influence of potential climatic changes in the Jambi region. Our objectives were (1) to asses villagers' perceptions of changes in the local water cycle in an oil palm dominated region, (2) to identify environmental processes leading to changes in the water cycle, (3) to confront the perceived changes with empirically derived environmental data, and thus (4) to derive complementary lines of argument to discuss environmental perceptions in the context of the actual underlying ecohydrological processes.

\section{The hydrosocial cycle and environmental perceptions}

The hydrosocial cycle (after Linton and Budds 2014) serves as a framework to analyze water as a product of society-nature interrelations. Although the concept of the hydrological cycle focuses only on the material components of water, the way that water actually flows through landscapes is drastically shaped by human institutions, practices, and discourses (Linton and Budds 2014). Water can therefore be considered something inherently political, because the control over water produces certain types of social power relations and structures (Wittfogel 1957). The hydrosocial cycle builds upon the notion of water as a "hybrid" object (Latour 1993), i.e., one that simultaneously possesses a social and a natural dimension that are engaged dialectically as both product and agent of socio-natural change (Swyngedouw 2004). Water is thus considered to have a material energetic dimension, such as the flow of water that can change landscapes and established social orders and that provides the basis for individual or societal claims, as well as a cultural-symbolic dimension formed by symbolic orders, interpretive contexts, and social constructions (Becker et al. 2011). The hydrosocial cycle can thus be defined as a socio-natural process by which water and society interact materially and discursively (Linton and Budds 2014). In order to untangle the social and natural processes coproducing this hybrid nature of water, we combined qualitative social field research with natural science empiric measurements in this study.

From the social science perspective, we approach the hybridity of water through environmental perceptions. Environmental perceptions can be defined as the "reception and processing of information from the environment" (Ittelson 1973:4). This includes both the assessment and the evaluation of information, which implies embedding the environmental context into individual experiences, imaginations, and memories (Schiffman 1982, Bell et al. 2001). As such, the way in which individuals analyze the environment and environmental changes is influenced in particular by environmental knowledge and values, place attachment, interests and motivations, but also by the specific prevailing circumstances such as time or cause of environmental change (Hellbrück and Fischer 2003, Chokor et al. 2004, Brown et al. 2005, Sampaio Sieber et al. 2011, Boelens 2014). Environmental perceptions thus have to be understood as context-related, dynamic, and discursively formed knowledge that is open to negotiation and change (Irwin 2001). Accordingly, both conformity and nonconformity of environmental perceptions vs. measured environmental processes have been reported (e.g., Moser 1984, Poor et al. 2001, Artell et al. 2013, Cottet et al. 2013).

\section{METHODS}

\section{Study region}

Our research is part of EFForTS, an interdisciplinary research project investigating ecological and socioeconomic functions of tropical lowland rainforest transformation systems (http://www. uni-goettingen.de/crc990; Faust et al. 2013, Drescher et al. 2016). The study region of EFForTS is Jambi Province in the eastern lowlands of Sumatra, Indonesia. The field work for this study was carried out in the South of Jambi Province, in and around Bungku village (Fig. 1). Climate in the region is tropical humid $\left(26.5^{\circ} \mathrm{C}, 2235 \mathrm{~mm}\right.$ year ${ }^{-1}$, based on data from the meteorological station at the airport Sulthan Thaha, Jambi), with a relatively dry season from June to September (monthly precipitation often below $120 \mathrm{~mm}$ ). Between 1985 and 2007, 1.7 million ha of forest were cleared in the lowland areas $(<150 \mathrm{~m}$ elevation) of Jambi province, which corresponds to $71 \%$ of the 1985 forest area (Laumonier et al. 2010). Today, mono-culture rubber and oil palm plantations dominate the landscape. Rubber has been cultivated in Jambi since Dutch colonial times (Feintrenie and Levang 2009); oil palm cultivation started in the mid-1980s and expanded to almost 600,000 ha in 2013 (BPS Jambi 2014).

The Bungku village spreads over an area of $600 \mathrm{~km}^{2}$ and comprises five hamlets. The social scientist case study was conducted in two neighboring hamlets in northern Bungku, Bungku Indah and Johor Baru 1 (see Fig.1). Until the 1980s, Bungku was still dominantly covered by forest areas, extensive rubber agroforests, and shifting cultivation land-use systems. Since then, intensive logging, the expansion of rubber plantations, and the 
Fig. 1. Location of the study sites in Jambi province, Sumatra, Indonesia.

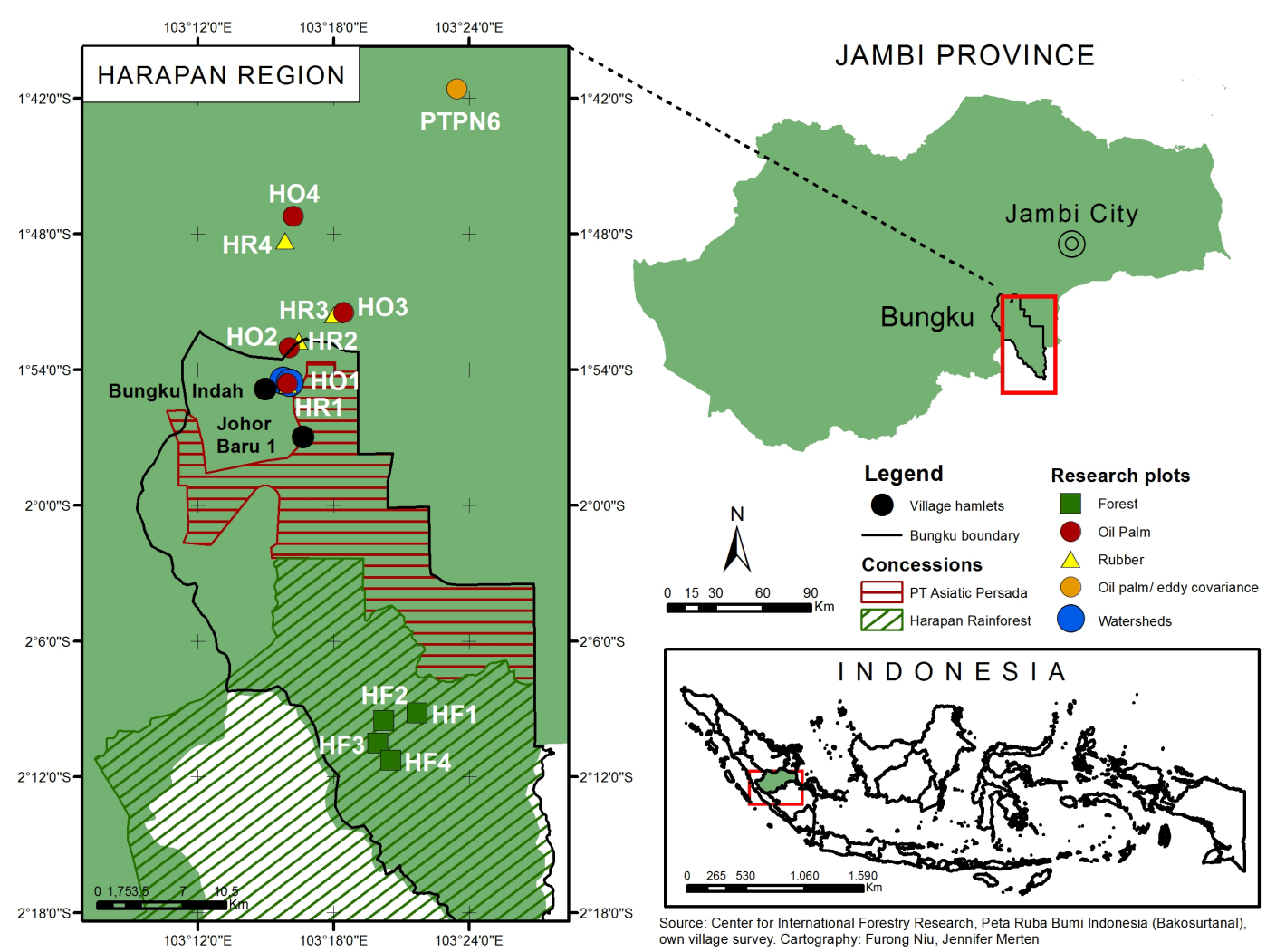

establishment of oil palm plantations, which was promoted particularly since the mid-1990s (Colchester et al. 2011), led to rapid deforestation. Today, natural vegetation can only be found in patches in the Harapan Rainforest, a forest rehabilitation project in the southern area of Bungku (Fig. 1). In 2013, land use in Bungku Indah was characterized by about $60 \%$ rubber and $40 \%$ oil palm cultivation, with oil palm strongly increasing in recent years (personal communication with village head); Johor Baru 1 was predominantly characterized by industrial and smallholder oil palm plantations. The company PT Asiatic Persada holds an oil palm concession of 20,000 ha directly bordering the Johor Baru 1 (Fig. 1). Indigenous land claims inside the concession area have been oppressed since the granting of the concession in 1987. The plantation has ever since been the subject of an ongoing land-use conflict involving numerous national and international actors (for more details see Colchester et al. 2011, Steinebach 2013, Beckert et al. 2014, Hauser-Schäublin and Steinebach 2014).

Through constant in-migration from other parts of Jambi and Indonesia the population of Bungku has grown significantly over the last decades. Although the initial settlement project in the early 1970 s only comprised roughly 60 households, the village population in 2015 had grown to 10,798 people (HauserSchäublin and Steinebach 2014, BPS Kabupaten Batang Hari 2015). About $10 \%$ of today's population are indigenous people, $55 \%$ are migrants from Java, 30\% are migrants from other parts of Sumatra/Jambi province, and 5\% come from other parts of
Indonesia (personal communication with village head). Public infrastructure in Bungku was generally poor at the time of investigation (June 2013). Roads had a severely degraded asphalt cover and public electricity and water supply did not exist. More well-off households had electricity from diesel generators. Household wells, sometimes shared among neighboring families, represented the main water supply for Bungku villagers. These wells differed significantly in construction type, ranging from nonsecured holes adjacent to small rivers to deeper wells secured with cement. Water from these wells was often pumped to the houses with electric pumps. Bottled water has been for sale in Bungku since 2009. Since then, most households buy bottled water for drinking and often also for cooking. Well water is used for people's personal hygiene and washing dishes and clothes (personal observations).

The environmental study plots were located on upland mineral soils; soil type is loam Acrisol (Allen et al. 2015), which is characterized by a clay accumulation horizon at a depth of $20-$ $50 \mathrm{~cm}$. Measurements were taken on four plots each in oil palm monocultures (HO1 - HO4), in rubber monocultures (HR1 HR4), and in forest reference sites (HF1 - HF4, Fig. 1). Each of these 12 plots was $50 \mathrm{~m} \times 50 \mathrm{~m}$ in size. The oil palm and rubber plots were located in the vicinity (up to $15 \mathrm{~km}$ ) of the village of Bungku. Management characteristics as well as agroecological site conditions were typical for smallholder plantations in Bungku (personal observation). Plantation ages ranged from 7 to 16 years; the plantations were smallholder properties. The forest plots were 
located in the Harapan Rainforest, $30 \mathrm{~km}$ from Bungku Indah. The Harapan Rainforest was partially severely logged until approximately 2003 and became a conservation and restoration area in 2010. Additional measurements were taken in a 12-yearold large-scale oil palm plantation $25 \mathrm{~km}$ from Bungku (PTPN6, Fig. 1). For further details on the study region and the overall study design of the EFForTS project, refer to Faust et al. 2013 and Drescher et al. 2016.

\section{Social dimension}

Based on initial reports about water scarcity in areas surrounding oil palm plantations in Jambi, interest by social and natural scientists led to an inductive social case study. Bungku was chosen because of reports of rapid land-use changes and increasing water scarcity. The case study aimed at investigating villagers' perceptions of major environmental changes, challenges in the local water supply, and processes that potentially cause problems for the water supply.

To investigate these questions we conducted problem-centered, semistructured household interviews (after Mayring 2002; $\mathrm{n}=30$ ) that were triangulated with participatory observation, informal interviews, focus group discussions, and participatory rural appraisal tools, i.e., timeline interviews and resource mapping (after Kumar 2002). Field work in Jambi was conducted during a period of eight weeks from May to July 2013. Respondents were chosen according to the snowball sampling method (Schnell et al. 2013), trying to reflect the social structure of the hamlets. Supplementary information was obtained through nine key informant interviews with representatives of the private sector, civil society organizations, and public authorities at the regional and national level. For further details on interview procedures and data processing refer to Appendix 1.

During the research process it became clear that changes in the local water cycle could not easily be separated from the political discourse about them. We thus chose the hydrosocial cycle as a conceptual framework to cope with these existing ambiguities and to analyze the different dimensions of socio-natural relations. Applying this framework, the social and natural scientists involved in the study jointly discussed if and how the villagers' perceptions from the social case study could be explained by empirical environmental datasets.

\section{Environmental patterns and processes}

\section{Land-use change}

In the PTPN6 large-scale oil palm plantation (Fig. 1), the eddy covariance technique (Baldocchi 2003) was used to measure evapotranspiration, the three components of the wind vector (METEK USA-1, Elmshorn, Germany), as well as water fluxes (LICOR 7500, Lincoln, USA). We used data from three sunny days during October and November 2014 to minimize day-to-day variability induced by weather.

Transpiration rates, soil erosion, air temperature under the canopy, and soil moisture fluctuations were studied on oil palm, rubber, and forest plots (HO1 - HO4, HR1 - HR4, and HF1 HF4, Fig. 1). To estimate stand transpiration rates we measured sap flux densities with thermal dissipation probes (Granier 1985, 1996) in these 12 plots as well as at the PTPN6 site. For measurements in oil palm leaf petioles, we used the calibration and sampling scheme as proposed by Niu et al. (2015). The standard equation (Granier 1985) was used for trees in rubber and forest plots. For trees, radial profiles of changes in sap flux density with xylem depth were established. To extrapolate from trees and palms to stand transpiration, inventory data were used (Kotowska et al. 2015). Because measurements were partly not conducted simultaneously, we also averaged the values of three sunny days for the analysis to minimize variability induced by weather. More details on these and all other applied methods can be found in Appendix 1.

On the 12 forest and plantation plots, the soil carbon content in the $\mathrm{Ah}$ horizon (down to max $10 \mathrm{~cm}$ depth) was measured (Guillaume et al. 2015) and soil erosion was estimated by assessing the soil carbon isotopic composition $\left(\delta^{13} \mathrm{C}\right)$ with depth. The $\delta^{13} \mathrm{C}$ profiles in the plantations were compared with the forest reference plots, where erosion was assumed to be zero. This was necessary to estimate the thickness of the surface layer lost by erosion after forest conversion. To assess fluctuations in microclimate (air temperature, air humidity, and soil moisture), weather stations equipped with thermohygrometers (Galltec Mella, Bondorf, Germany) and soil moisture sensors (IMKO Trime-PICO, Ettlingen, Germany) were installed on the 12 study plots.

Within two small catchments encompassing some of the oil palm and rubber plots (HO1 - 4, HR1 - 4, Fig. 1), we recorded streamflow and measured rainfall interception for four months. One catchment (14.2 ha in size) was dominated by 10 - 14-yearold oil palm plantations (covering $90 \%$ of the catchment area). The other catchment ( 4.9 ha) consisted of different rubber stands: 8 -year-old (19\% of the catchment area) and 30-year-old (56\% of the area) mono-culture rubber plantations and jungle rubber ( $25 \%$ of the area), a mix of rubber trees and naturally established dicot tree species. We selected a two-week period (7 to $20 \mathrm{Nov}$ 2013) of the recorded hydrographs encompassing both dry and rainy conditions. Rainfall interception of the oil palm and rubber monocultures in the respective catchments was assessed by measuring throughfall and stemflow, and subtracting them from incident rainfall.

\section{Climate change}

For the period from 1991-2011, we analyzed air temperature and rainfall data from the meteorological station located at Airport Sultan Thaha, Jambi, property of the Indonesian meteorological service (BMKG). Our aim was to assess whether there have been climatic changes in Jambi over the last 20 years. Mean, maximum, and minimum temperature as well as rainfall data were separated in to their time components to detect trends in these variables over the last years. For an analysis of climatic trends on a greater temporal scale, we calculated the Standardized Precipitation Evapotranspiration Index (SPEI) from the Global SPEI Database (SPEIbase; Vicente-Serrano et al. 2010) for the Bungku region from 1901-2011. The SPEI is a multiscalar drought index that takes into account precipitation and potential evapotranspiration to determine drought conditions; a strong drought is reflected by a large negative value.

\section{RESULTS}

\section{Social perspectives on changes in water availability}

To structure and analyze the environmental perception of the villagers we first describe people's assessments of environmental changes that they observed during their time in Bungku, and 
Table 1. Representative quotes from the interviews and group discussions ${ }^{\dagger}$ of the social case study. Interviews were conducted in the village of Bungku, Jambi, from May to July 2013.

On the drying of surface and subsurface waters

"Before when people didn't open much of the forest yet there was still water in the river and it still flowed after one month of drought. But since people opened the forest and plant oil palms the water in the river gets less. It doesn't flow anymore."

"When there was still a lot of forest around Bungku even during a drought of two months we still had water in our wells. But now there is no forest anymore, there is oil palm."

"Before there were not so many oil palms. That's why we still had enough water. Because oil palm needs a lot of water, while rubber can keep the water."

'The negative thing about oil palm is that it is a plant that needs a lot of water. That's why, if we plant oil palm near swamp areas, after some time the swamp will run dry."

Middle-class rubber farmer, Javanese, has lived in Bungku since 1999, 60 years old.

Owner of a kiosk where bottled water is sold, has lived in Bungku since 1995, Javanese, $\sim 50$ years old. Rich woman, born in Bungku, $\sim 30$ years old.

Rich oil palm farmer during group discussion, Javanese, $\sim 35$ years old.

On the increasing pollution of local water resources

"Did you observe any changes in the water quality?" "Yes, it changed. A lot! Before the water was not that dark, but now it looks like it contains mud. Before there was not that much mud in the water."

"After rainfall the water in the well becomes turbid. But after some days without rain the water quality gets better again."

"The problem comes from the people themselves. The habit of the people here is that if there is no rain for some weeks then they start to go fishing. But they use toxics. And another reason is that the people who live near a river take a shower and wash their dishes in the river. And sometimes they also throw the garbage in the river."

"The people now have a problem with the water. The water quality of the river is not good anymore. But they still use it for washing and showering since there is no clean water tetangga, neighbor solidarity unit), 40 years old. anymore."

On increasing local temperatures

"When I came to Bungku in 1991 the temperature was different. There was still a lot of forest and the temperature was not as hot as today."

Poor, very old woman selling food at a small stand, has lived in Bungku since 1987.

Young, middle-class woman, has lived in Bungku since her childhood, $\sim 30$ years old.

Nurse, has lived in the district for 15 years, $\sim 30$ years old.

"If we are standing under an oil palm and afterwards under a rubber tree and we compare it, then the temperature feels very hot under the oil palm trees."

Very rich woman, has lived in Bungku since 1991, Javanese, owns rubber and oil palm cultivations, 29 years old.

Oil palm farmer during group discussion, has lived in Bungku since 1993, Javanese, $\sim 40$ years old.

${ }^{\top}$ Translations by J. Merten and I. Kasmudin.

secondly people's personal evaluations of these changes. Finally, we discuss impacts on local water supply as a consequence of a decreasing availability of clean water.

Villagers' assessments of changes in local water resources Over the last 25 years, the villagers of Bungku observed pronounced changes of local water resources. Among the observations mentioned were a faster depletion of groundwater reservoirs during dry periods, a higher fluctuation of river levels with particularly low levels during dry seasons, and an increased pollution of surface waters (see Table 1). The fast depletion of groundwater levels during dry seasons was of particular importance to the villagers because their water supply was mainly ensured by household wells. Wells that dried up in past decades have also been reported. However, the consensus among interviewed villagers in Bungku was that during dry periods the scarcity of well water has started to occur much faster and more frequently since the early 2000 s. They observed that since then, in times of prolonged dry periods, many wells in the village fall dry.

In addition to the fast groundwater depletion, community members reported that streamflow levels decrease much faster during dry seasons than had been the case 10 years ago; several smaller rivers stopped flowing after only a few weeks without rain. Swampy areas are generally numerous along streams and rivers in the research region. However, over the past years, many of them were observed to have started to decrease in extent and depth, or to have dried out completely. During the rainy season, very high river levels with quick declines after rainfall events were observed in recent years.

The interviewed villagers also mentioned alterations in water quality. Water quality was reported to have decreased significantly over the past decades, described as changes in water color from "clean" and "pure" in the past to "turbid" and "muddy" at the time of research. Water quality was said to be particularly bad in times of water scarcity. When a lot of wells in Bungku run dry, many villagers rely on surface water for personal hygiene. This then generates further pollution particularly of shallow or stagnant water bodies.

The challenge in accessing clean water was also recognized by an official document on the village development. "Difficult access to clean water" was ranked among the four most urgent issues for all five village hamlets. An additional factor possibly interconnected to seasonal water scarcity in Bungku was the observation of increasing air temperature. Villagers felt it had become significantly hotter since oil palm plantations started to dominate large parts of the landscape surrounding the village.

\section{Local evaluations of increasing seasonal water scarcity}

The explanations by the villagers for the observed changes in local water supply were manifold but were all directly or indirectly 
related to the ongoing land-use change in the Bungku region. The explanations given for decreasing groundwater and streamflow levels during dry seasons included particularly the ongoing deforestation and the expansion of oil palm cultivation (see Table 1). Water availability was observed to have decreased notably after oil palms became the dominant element in the landscape. Common stories in the village attributed an allegedly high water use to oil palms, which was believed to cause adjacent swamp areas, rivers, and wells to run dry. Rubber plantations, on the other hand, were believed to rather "conserve" or "store" water in the soil. Some villagers reported that wells they built in oil palm plantations ran dry after only a few weeks without rainfall, while wells inside rubber plantations provided water even during prolonged dry periods. Further explanations for the low streamflow of local rivers brought forward by individual villagers included landscape-shaping activities of oil palm companies, e.g., draining of swamps, channelization of rivers, or inadequate canalization in road construction.

Key informants reported that increasing pollution of surface waters was likely related to the behavior of the villagers themselves (see Table 1). The main issues mentioned by the interviewees were the lack of waste and wastewater management in the village, the use of surface waters for personal hygiene, and the use of poison for fishing. The rapid population growth in the village added to this by causing a constantly increasing volume of waste and wastewater. With respect to oil palm cultivation, individual villagers blamed the lack of environmental management and the absence of buffer zones along rivers for increases in the sediment load of local rivers over the last years. Fertilizer and possibly pesticide leaching were reported to be further sources of pollution in other studies (e.g., Banabas et al. 2008, Comte et al. 2012, Obidzinski et al. 2012, Larsen et al. 2014, Allen et al. 2015), but were only mentioned by few villagers in our study.

The evaluations presented above reflect the general opinion of the respondents in Bungku, including both rubber and oil palm farmers. Some indigenous farmers and long-time residents, however, presented different evaluations of local developments. They emphasized that oil palms per se cause most environmental degradations occurring in the area and are, e.g., also particularly "water-greedy." In contrast to this, individual, more prosperous oil palm farmers, company representatives, and local representatives of policy institutions negated most negative environmental impacts of oil palm expansion, rather stressing the economic benefits.

Impacts of decreasing water availability on local water supply As a consequence of local water scarcity during prolonged dry seasons, the majority of the interviewed households were forced to access different, more abundant water resources. These were often at a distance of up to 10 kilometers from the village. Only those few households possessing a car could transport an amount of water lasting for a couple of days. Poorer families had to rely on richer neighbors to carry additional water for them. Trucks with water tanks could be ordered to the village, but apart from significant costs this implied possessing major storage facilities, which most households did not have. Thus, many households tried to reduce their water consumption and used bottled water for the most essential uses, i.e., drinking, cooking, washing infants. The sale of bottled water at kiosks in the village was reported to roughly double during dry seasons. Concerning personal hygiene, laundry, and the cleaning of cooking facilities, many people sought any other available source of water in and around the village, commonly of poor water quality, e.g., small swamps and rivers. According to statistics of the community health center, skin diseases and allergies were the second most common diseases (after upper respiratory tract infections) in Bungku at the time of investigation. People suffering skin allergies were generally recommended to use bottled water for showering. The degradation of water quality was also reported to lead to substantial declines in fish stocks, forcing villagers to go fishing at the rather distant larger streams near the Harapan Rainforest or to rely on aquaculture.

\section{Environmental patterns and processes}

\section{Land-use change}

Evapotranspiration rates derived from the eddy covariance technique in a 12-year-old oil palm plantation in Jambi (PTPN6) were $4.7 \pm 0.1 \mathrm{~mm} \mathrm{day}^{-1}$ (three sunny days, mean \pm SE; Table 2). On the same days (and in the same plantation, PTPN6), transpiration by the oil palms as derived from sap flux measurements was estimated to be $2.5 \pm 0.1 \mathrm{~mm} \mathrm{day}^{-1}$; the remaining $47 \%$ of evapotranspiration are likely the sum of transpiration by other plants, e.g. ground vegetation or trunk epiphytes, and evaporation, e.g., from the soil.

Table 2. Characteristics of the water cycle and connected variables of oil palm plantations, rubber plantations, and forest stands as observed in the lowlands of Jambi, Indonesia (n.d. - not determined).

\begin{tabular}{|c|c|c|c|c|}
\hline Variable & Method & Oil palm & Rubber & Forest \\
\hline Evapotranspiration $^{\dagger}$ & Eddy covariance & $4.7 \mathrm{~mm} \mathrm{~d}^{-1}$ & n.d. & n.d. \\
\hline Transpiration $^{\dagger}$ & Sap flux & $1.8 \mathrm{~mm} \mathrm{~d}^{-1}$ & lower & similar \\
\hline Rainfall interception & Rain gauges & $28 \%$ & lower & n.d. \\
\hline Soil carbon content & $\mathrm{CN}$ analyzer & $2.1 \%$ & similar & higher \\
\hline Stream base flow & Catchments & lower & higher & n.d. \\
\hline Stream storm flow & Catchments & high peaks & high peaks & n.d. \\
\hline Soil erosion ${ }^{\star}$ & d13C profiles & $35 \mathrm{~cm}$ & similar & n.d. \\
\hline Air temperature & Thermometers & $25^{\circ} \mathrm{C}$ & similar & lower \\
\hline
\end{tabular}

Average transpiration rates of the five oil palm plots (HO1 - 4, PTPN6) on sunny days were $1.8 \pm 0.3 \mathrm{~mm} \mathrm{day}^{-1}$ (three sunny days averaged for each plot; mean \pm SE represent spatial variability among the five mentioned oil palm plots), $11 \%$ lower than the average of the four forest plots (HF1 - 4, $2.0 \pm 0.2 \mathrm{~mm} \mathrm{day}^{-1}$ ). However, such a small difference lies within the uncertainties associated with the used approaches (see, e.g., Niu et al. 2015 for oil palm). The rubber plantations (HR $1-4,1.1 \pm 0.1 \mathrm{~mm} \mathrm{day}^{-1}$ ) had $85 \%$ lower average transpiration rates than forests and $63 \%$ lower than oil palm plantations. Additionally, rubber trees (partially) shed their leaves during the dry season, which effectively further reduced transpiration (by up to $70 \%$ at the peak of leaf shedding).

In the catchment areas, rainfall interception was $28 \%$ of incident rainfall in oil palm plantations, whereas it was $17 \%$ in rubber plantations. The observed difference is probably related to the high external trunk water storage capacity of oil palms, which we 
estimated to be $6 \mathrm{~mm}$ in a mature plantation in the oil palmdominated catchment. Butts of pruned petioles remain on the trunk over several years, forming chambers full of humus, water, and epiphytes.

Streamflow data from the two catchments confirmed differences between oil palm and rubber plantations: baseflow under dry conditions was lower in oil palm plantations $\left(1.81 \mathrm{~s}^{-1}\right.$ per ha catchment) than in rubber plantations $\left(8.21 \mathrm{~s}^{-1} \mathrm{ha}^{-1}\right)$. After intense rainfall events $(>60 \mathrm{~mm})$, recorded streamflow levels were strongly elevated in both catchments (up to $21.2 \mathrm{~s}^{-1} \mathrm{ha}^{-1}$ in the oil palm and $36.91 \mathrm{~s}^{-1} \mathrm{ha}^{-1}$ in the rubber catchment, respectively; Fig. 2).

Fig. 2. Streamflow patterns from oil palm dominated and rubber dominated catchments normalized by catchment area. Hydrographs from a two-week period (7 to 20 Nov 2013) encompassing both dry and rainy conditions.

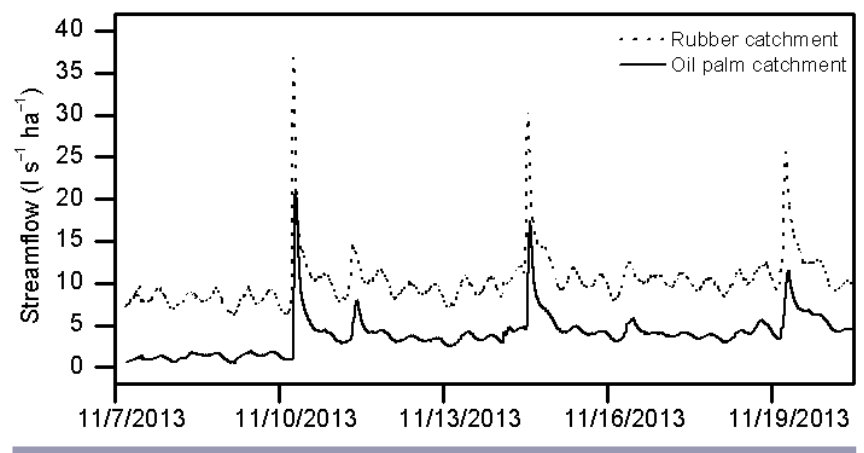

Soil erosion as derived from $\delta^{13} \mathrm{C}$ profiles as well as decreases in soil carbon content were similar in oil palm and rubber plots, averaging $35 \pm 8$ (mean $\pm \mathrm{SE}$ ) $\mathrm{cm}$ of top soil loss and amounting to $70 \%$ of $\mathrm{C}$ content decrease since conversion in oil palm plantations, and $33 \pm 10 \mathrm{~cm}$ and $62 \%$ in rubber plantations (Table 2; Guillaume et al. 2015). On forest plots, erosion was assumed to be zero (see Methods) and the C content in the Ah horizon was $6.8 \pm 0.8 \%$.

The analysis of microclimatic conditions inside the plots showed no clear patterns in soil moisture. We think a possible reason is that the variability within the plots was higher than the variability within the land-use systems and thus could not be assessed adequately by only one soil moisture sensor per plot. However, differences were observed in air temperature under the canopy, which was higher in oil palm and rubber than in the forest plots (by 0.4 and $0.5^{\circ} \mathrm{C}$ respectively, Table 2) and showed 1.5 -fold higher diurnal fluctuations in both plantation types than in the forest.

\section{Climate change}

The analysis of the SPEI indices over the past 100 years suggests that droughts are recurrent in Bungku area (Fig. 3), and that their frequency and intensity has not increased over the last century. The most severe droughts, reflected by a large negative SPEI index value (i.e., -1.5), occurred in 1924, 1983, and 1998; they are associated with strong El Niño Southern Oscillation (ENSO) events.

The evaluation of trends in air temperature and rainfall from 1991 to 2011 shows no significant changes in mean and maximum temperatures. However, the minimum temperature shows an increase of about $1{ }^{\circ} \mathrm{C}$ in the period from 2004-2011 ( $\left.\mathrm{p}<0.05\right)$, indicating a small decrease in the range of annual temperature variation. Rainfall, for 21 years with complete data series, was $2235 \pm 84 \mathrm{~mm}$ per year (mean $\pm \mathrm{SE}$ ). Rainfall in Jambi is characterized by a relatively dry period from June to September, when average monthly rainfall is often below $120 \mathrm{~mm}$. In some years such as 1993, 1994, or 2011, this dry season was more pronounced, with at least two consecutive months with monthly precipitation below $40 \mathrm{~mm}$. Other years, e.g., 2005, 2010, were wetter and the dry season was not very pronounced, indicating high variability in the rainfall patterns between years. Based on the evaluated data, we conclude that there were no significant climatic changes in Jambi between 1991 and 2011, and probably also not over the last century.

Fig. 3. SPEI index (standardized precipitation evapotranspiration index), a multiscalar drought index, for a 24-month period, from 1901 to 2011 in the Bungku region. Categorization of dryness by SPEI: Near normal (-1 to 1); Moderate dryness (-1.49 to -1$)$; Severe dryness (-1.99 to -1.5$)$; Extreme dryness (less than -2). Same ranges for positive values indicate wetness.

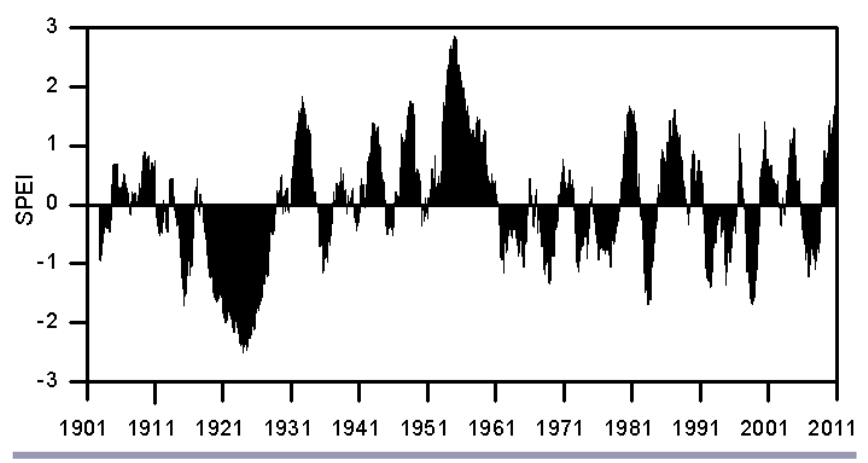

\section{DISCUSSION}

Environmental perceptions of changes in the local water cycle Our study suggests that water availability during dry periods is an increasing problem for the local population in the oil palmdominated landscape of our study region. The interviewed villagers reported that significant changes in the hydrological cycle have occurred in the study region over the last 25 years. The main concern of the interviewed villagers was the decline of surface and subsurface waters that they attributed to the rapid local land-use change from a landscape mosaic of forest and (agroforest) rubber patches to an increasingly oil palm-dominated land cover. Similar linkages between forest conversion and changes in local water supply have been observed in several studies, e.g., related to the development of payment for ecosystem services schemes (Pattanayak and Kramer 2001, Pattanayak 2004, Asquith et al. 2008, Muños-Piña et al. 2008, Lapeyre et al. 2015). Such schemes are, e.g., introduced to maintain watershed services from forest areas, including stable dry-season streamflow.

The villagers' perception in Bungku was that forest conversion to oil palm plantations impacted local water availability far more negatively than conversion to rubber monoculture plantations. In 
the opinion of the villagers, oil palm plantations use up a lot of the available water during dry seasons. These statements reflect the evaluation of the great majority of the interviewed villagers, independent of their social background and including dedicated oil palm farmers. This is in line with findings from a household survey in 45 villages in the Jambi province $(n=700$; Faust et al. 2013), which showed high awareness of villagers across all social groups of the environmental impacts of oil palm cultivation (M. Euler, V. Krishna, Z. Fathoni, S. Hermanto, S. Schwarze, and M. Qaim 2012, unpublished data). Drying wells and surface waters in the surroundings of oil palm plantations were also reported in studies by Obidzinski et al. (2012), Larsen et al. (2014), and an NGO report by Friends of the Earth et al. (2008).

Two small groups of interviewees, however, propagated different evaluations of the local development. Depending on their social background and their (non)participation in the profitable oil palm business, they either overemphasized or completely neglected negative hydrological impacts by oil palm expansion. This demonstrates that the local discourse on water supply is deeply embedded into a wider discourse on consequences of the regional land-use change. Local water supply is being used as an argument to substantiate personal claims and viewpoints regarding the drastic expansion of monoculture oil palm plantations in the region. The actor groups that vigorously advocated the advantages of oil palm business are among the winners of the ongoing land-use change to agricultural systems. On the other hand, poorer smallholders and indigenous people are confronted with large agricultural investors, which make access to land in the region increasingly unaffordable. Considering the diverse nature of the ongoing land-use conflicts in the area, the described politicization of water scarcity is not surprising. Steinebach (2013), Hein and Faust (2014), and Hein et al. (2015) have extensively described how indigenous people and poor farmers in the area form strategic coalitions and engage in environmental justice discourses to legitimize and strengthen their political claims of access to land and natural resources.

As a consequence of regularly dried up wells, households were forced to access more abundant but often quite distant water resources. The transport of water from these sources heavily depended on access to motorized vehicles. Access to clean water thus was highly dependent on the households' financial situation, i.e., the available capital for purchasing bottled water or ordering larger tanks of water. According to our observations, buying water for drinking and cooking could be afforded by most interviewed households in Bungku, whereas the use of bottled water for showering or other high-water activities would stress household finances substantially. Access to water thus strongly increased social polarizations, further disadvantaging those not participating in the profitable oil palm business.

Cooperation among neighbors in times of need, i.e., times of local water scarcity, generally seemed strong regarding the provision of water. However, recounts of locked wells during the strong El Niño year in 1997 suggest that social cohesion might decline in times of extreme scarcity, which poses risks of social unrest.

In times of scarcity, the increasing use of surface waters for personal hygiene, along with the rapid population growth of past decades, put enormous pressure on local water bodies. Consequently, water from small and highly frequented local water bodies was commonly observed to be of extremely poor quality, which might be a significant cause of diseases, e.g., of the skin. Even the water of larger rivers in Jambi cannot be considered safe because of possible leaching of agrochemicals from surrounding plantations (Comte et al. 2012, Allen et al. 2015) or upstream gold mining activities. For the Muslim majority of the village, this does not only impose problems regarding health, but also regarding religious customs. Clean water is indispensable for the ritual washing before prayers, fast breaking, funerals, and other religious celebrations.

\section{Environmental processes leading to changes in the water cycle}

Evapotranspiration rates derived from eddy covariance measurements for a 12-year-old oil palm plantation (PTPN6) under dry, sunny conditions were similar $\left(4.7 \mathrm{~mm} \mathrm{day}^{-1}\right)$ to values reported for lowland rainforests on Borneo (4.2 $\mathrm{mm} \mathrm{day}^{-1}$ on annual average; Kumagai et al. 2005) and rainforests in Peninsular Malaysia (4.2 mm day ${ }^{-1}$ on annual average; Tani et al. 2003). The transpiration estimate derived from sap flux measurements for the same oil palm plantation $\left(2.5 \mathrm{~mm} \mathrm{day}^{-1}\right)$ was the highest among the five oil palm plantations assessed in this study, and also among 15 different oil palm plantations of varying age in the greater study region (Röll et al. 2015). It was also similar to the highest transpiration rate among the four forest plots $\left(2.4 \mathrm{~mm} \mathrm{day}^{-1}\right)$. Our oil palm and forest transpiration estimates are similar to transpiration rates reported for tropical forest sites in Indonesia and Australia (1.3 - 2.6 mm day ${ }^{-1}$; Calder et al. 1986, Becker 1996, McJannet et al. 2007). This suggests that oil palms can transpire at substantial rates under certain conditions, despite, e.g., their much lower biomass per hectare compared to forests (Kotowska et al. 2015). Among all studied plots, the sap flux-derived estimates for average oil palm and forest transpiration rates are similar, but rubber plantations transpire at more than $60 \%$ lower rates under similar conditions. Also, rubber trees partially shed their leaves in pronounced dry periods, which further reduces transpiration by up to $70 \%$ explicitly in times of water scarcity. In addition to the much lower re-evaporation of water to the atmosphere, rainfall interception by rubber plantations is 1.7 -fold lower than by oil palm plantations ( $28 \%$ of incident rainfall); our values for interception fall into the range of values reported for tropical forests in South East Asia (commonly 10-30\%, e.g., Dykes 1997, Kumagai et al. 2004, Dietz et al. 2006). The differences in transpiration and interception can explain the lower baseflow from oil palm dominated catchments as compared to rubber dominated catchments that we observed.

Soil water infiltration capacities represented by Ks-values derived from ring infiltrometer experiments for different land-use types in the study region were reported to decrease from forest $(47 \mathrm{~cm}$ $\left.\mathrm{hr}^{-1}\right)$ via rubber $\left(7 \mathrm{~cm} \mathrm{hr}^{-1}\right.$ on harvesting paths, $7.8 \mathrm{~cm} \mathrm{hr}^{-1}$ between rubber trees) to oil palm plantations $\left(3 \mathrm{~cm} \mathrm{hr}^{-1}\right.$ on harvesting paths and weeding circles; S. Tarigan and Sunarti, unpublished data). The much lower infiltration capacities in plantations as compared to forest are consistent with the observed strong decline of soil quality after forest conversion, i.e., decrease in $\mathrm{C}$ content and erosion (Guillaume et al. 2015, 2016). C content plays a key-role in soil aggregation (Franzluebbers 2002, Bronick and Lal 2005), while erosion brings deeper and denser soil layers to the soil surface. Thus, both are associated with lower soil permeability. Such soil degradation after forest conversion was also observed in similar land-use types in Malaysia (Gharibreza et al. 2013), 
China (de Blécourt et al. 2013), and Ghana (Chiti et al. 2014). Although the extent of soil degradation was similar between rubber and oil palm plantations, soil characteristics are more heterogeneous in oil palm plantations, i.e., soil organic carbon content is lower in inter-rows (Frazão et al. 2013) and frequent and intensive management and harvesting operations increase soil compaction, e.g., on harvesting paths. The surfaces with the most degraded soil in oil palm plantations correspond to the locations where rainfall interception is low because of the incomplete canopy cover between palms ( $>20 \%$ gap fraction; Kotowska et al. 2015). This may explain the higher runoff as reflected by two-fold higher relative peak flows, i.e., normalized by baseflow, in oil palm than in rubber plantations.

In conjunction with the observed higher transpiration rates of oil palm as compared to rubber plantations, the increased runoff in oil palm plantations results in significantly less water being available for groundwater recharge after precipitation than in rubber plantations, and much less than in forested areas. Thus, groundwater recharge may be less efficient in oil palm dominated catchments than in rubber dominated ones, which may add to water scarcity during dry periods. Similar reductions in dry period baseflows and increases in postprecipitation peak flows after forest conversion have been reported in a variety of studies (e.g., Bruijnzeel and Bremmer 1989, Fritsch 1990, Sandström 1995, Elkaduwa and Sakthivadivel 1999, Zhou et al. 2002, Bruijnzeel 2004, Bonell et al. 2010, Zimmermann et al. 2010).

Our findings are consistent with the "sponge and pump" approach to hydrological effects of forest conversion (Bruijnzeel 2004, Peña Arancibia 2013). Forests may act as sponges by enhancing infiltration rates and moisture retention because of the effects of organic matter and the root network on soil physical properties, and act as pumps by transpiring large amounts of water into the atmosphere (see, e.g., Peña Arancibia 2013). In our study, both land-use types replacing the forest may have reduced the sponge effect. According to the "infiltration trade-off hypothesis" (Bruijnzeel 1986, 1989, 2004), the net effects of forest conversion on streamflow largely depend on the type of land cover replacing the forest. Baseflow (in dry periods) may be as high as in forested areas if losses in infiltration capacity are outbalanced by much lower (evapo)transpiration rates in the newly established land-use systems, which is often the case. In our study, the rubber plantations are such an example. The oil palm plantations, however, are different: we found soil degradation and thus low permeability as well as a high transfer of water vapor to the atmosphere. Combined, this can induce or enhance periodic water scarcity in oil palm dominated landscapes.

Confronting perceived changes with environmental measurements Our results suggest that rainfall volume and seasonal patterns did not change significantly since the beginning of oil palm expansion in the study region. Also, similar volumes of water are reevaporated back into the atmosphere from oil palm plantations and forests, but the penetration of water into the soil is reduced in oil palm plantations. Thus, much precipitated water leaves the landscape as surface runoff, causing streamflow to be high during rainfall events; less water remains in the soil under oil palms than in forested areas and groundwater recharge is decreased. In consequence, wells may dry out (earlier) during dry periods in oil palm dominated regions, as it was reported by the majority of interviewed Bungku villagers. The perception of extremely high water-use rates of oil palms as the main cause for increased seasonal water scarcity among some Bungku villagers does not match the results of our evapotranspiration and transpiration measurements. However, the people's perception that the regional oil palm expansion may be responsible for local water scarcity during dry periods is backed by several results from environmental measurements. We also have indications that there are significant differences in eco-hydrological characteristics (particularly in transpiration rates) between oil palm and rubber plantations, as observed by several villagers.

Our matching of social perceptions and environmental measurements thus provides manifold explanations for changes in the physical water cycle. The major force behind these changes is the rapidly expanding oil palm business, which constitutes the main driver of deforestation and land-use change in the area (Colchester et al. 2011). Changes in the local water cycle are not only caused by soil degradation under oil palms but also through the channelization of rivers and the draining of swamp areas by oil palm companies (personal observations in the field and from satellite images). These shifts in the physical water flows mirror changing societal power relations that accompany the conversion of an originally forest-dominated area toward an intensively managed agroindustrial landscape (see Beckert et al. 2014, Brad et al. 2015, Hein et al. 2015). Water, a formerly abundant common pool resource, today is becoming a scarce resource during dry seasons. In such times of water scarcity, people have to reorganize their daily life around the constant "search for water." Water is consequently increasingly treated as a commodity rather than a common pool resource. This capitalization increases social polarizations in the village between winners of land-use change and underprivileged social groups such as indigenous people or poorer farmers. In the light of decreasing access to land (Colchester et al. 2011, Beckert et al. 2014, Hauser-Schäublin and Steinebach 2014, Hein et al. 2015), the access to clean water has turned into an additional argument to substantiate political claims in local contestations over access to land and natural resources. Our social and environmental analysis of different components and processes of the hydrosocial cycle in Bungku thus clearly depicts the complexity of local water-society relations. It serves as an example of how local land-use change triggers both material and discursive changes in the hydrosocial cycle, i.e., the occurrence of local water scarcity as well as its local interpretation by different social groups.

\section{CONCLUSIONS}

Water shortages were reported to occur more often since oil palm cultivation has become the dominant land use and large-scale deforestation has taken place. Several villagers strongly emphasized that oil palm is a major consumer of water and thus largely responsible for decreasing local water tables and water supplies. Analyses of environmental processes generally supported this perception and also confirmed differences between rubber and oil palm plantations. However, there is some added eco-hydrological complexity to the local interpretations. Our evapotranspiration data indicate that oil palm plantations use about as much water as forests for transpiration. Rather than to high water use of oil palms per se, local water scarcity seems connected to the redistribution of water after precipitation at the landscape scale. In natural ecosystems, e.g., forest, the largest part 
of rainfall water is taken up by the soil and contributes to the transpiration of plants and groundwater recharge. Under oil palm plantations, however, precipitated water cannot well penetrate the eroded and compacted soil. Consequently, a significant amount of water leaves the landscape as runoff and less water is available for groundwater recharge. Large-scale conversion of natural forests to oil palm plantations thus induces or enhances periodic water scarcity.

\section{AUTHOR CONTRIBUTIONS}

Jennifer Merten and Alexander Röll contributed equally to the study in terms of coordinating, contributing data and ideas, and the amount of time spent writing and revising the manuscript. Jennifer Merten coordinated the human dimensions part of the study, Alexander Röll the natural science part.

Responses to this article can be read online at: http://www.ecologyandsociety.org/issues/responses. $\mathrm{php} / 8214$

\begin{abstract}
Acknowledgments:
This study was supported by a grant from the German Research Foundation (DFG) in the framework of the Collaborative Research Centre 990 (http://www.uni-goettingen.delcrc990). Jennifer Merten received a grant from the Heinrich-Böll Foundation. We greatly thank all our Indonesian counterparts for their assistance during field work. Special thanks to all our Indonesian field assistants who made the extensive field work possible. Terimakasih! Finally, we thank the two anonymous reviewers for their constructive comments. Jennifer Merten and Alexander Röll contributed equally to the manuscript.
\end{abstract}

\section{LITERATURE CITED}

Allen, K., M. D. Corre, A. Tjoa, and E. Veldkamp. 2015: Soil nitrogen-cycling responses to conversion of lowland forests to oil palm and rubber plantations in Sumatra, Indonesia. PLOS ONE 10(7):e0133325. http://dx.doi.org/10.1371/journal.pone.0133325

Artell, J., H. Ahtiainen, and E. Pouta. 2013. Subjective vs. objective measures in the valuation of water quality. Journal of Environmental Management 130:288-296. http://dx.doi.org/10.1016/ j.jenvman.2013.09.007

Asquith, N. M., M. T. Vargas, and S. Wunder. 2008. Selling two environmental services: in-kind payments for bird habitat and watershed protection in Los Negros, Bolivia. Ecological Economics 65(4):675-684. http://dx.doi.org/10.1016/j. ecolecon.2007.12.014

Babel, M. S., B. Shrestha, and S. R. Perret. 2011. Hydrological impacts of biofuel production: a case study of the Khlong Phlo watershed in Thailand. Agricultural Water Management 101 (1):8-26. http://dx.doi.org/10.1016/j.agwat.2011.08.019

Badan Pusat Statistik (BPS) Kabupaten Batang Hari. 2015. Kecamatan Bajubang dalam angka 2015. BPS Kabupaten Batang Hari, Indonesia. [online] URL: http://batangharikab.bps.go.id/ backend1/pdf_publikasi/Kecamatan-Bajubang-Dalam-AngkaTahun-2015--.pdf
Badan Pusat Statistik (BPS) Provinsi Jambi. 2014. Jambi dalam angka 2014. BPS Jambi, Indonesia. [online] URL: http://jambi. bps.go.id/website/pdf publikasi/Jambi-Dalam-Angka-2014.pdf

Baldocchi, D. D. 2003. Assessing the eddy covariance technique for evaluating carbon dioxide exchange rates of ecosystems: past, present and future. Global Change Biology 9:479-492. http://dx. doi.org/10.1046/j.1365-2486.2003.00629.X

Banabas, M., M. A. Turner, D. R. Scotter, and P. N. Nelson. 2008. Losses of nitrogen fertiliser under oil palm in Papua New Guinea: 1. Water balance, and nitrogen in soil solution and runoff. Soil Research 46(4):332-339. http://dx.doi.org/10.1071/SR07171

Becker, P. 1996. Sap flow in Bornean heath and dipterocarp forest trees during wet and dry periods. Tree Physiology 16:295-299. http://dx.doi.org/10.1093/treephys/16.1-2.295

Becker, E., D. Hummel, and T. Jahn. 2011. Gesellschaftliche Naturverhältnisse als Rahmenkonzept. Pages 75-96 in M. Groß, editor. Handbuch Umweltsoziologie. Springer, Wiesbaden, Germany. http://dx.doi.org/10.1007/978-3-531-93097-8_4

Beckert, B., C. Dittrich, and S. Adiwibowo. 2014. Contested land: an analysis of multi-layered conflicts in Jambi Province, Sumatra, Indonesia. Austrian Journal of South-East Asian Studies 7 (1):75-92.

Bell, P. A., T. C. Greene, J. D. Fisher, and A. Baum. 2001. Environmental psychology. Fifth edition. Hartcourt College Publishers, Fort Worth, Texas, USA.

Binder, C. R., J. Hinkel, P. W. G. Bots, and C. Pahl-Wostl. 2013. Comparison of frameworks for analyzing social-ecological systems. Ecology and Society 18(4):26. http://dx.doi.org/10.5751/ es-05551-180426

Bodin, Ö., and M. Tengö. 2012. Disentangling intangible socialecological systems. Global Environmental Change 22:430-439. http://dx.doi.org/10.1016/j.gloenvcha.2012.01.005

Boelens, R. 2014. Cultural politics and the hydrosocial cycle: water, power and identity in the Andean highlands. Geoforum 57 (November 2014):234-247. http://dx.doi.org/10.1016/j. geoforum.2013.02.008

Bonell, M., B. K. Purandara, B. Venkatesh, J. Krishnaswamy, H. A. K. Acharya, U. V. Singh, R. Jayakumar, and N. Chappell. 2010. The impact of forest use and reforestation on soil hydraulic conductivity in the Western Ghats of India: implications for surface and sub-surface hydrology. Journal of Hydrology 391 (1):47-62. http://dx.doi.org/10.1016/j.jhydrol.2010.07.004

Brad, A., A. Schaffartzik, M. Pichler, and C. Plank. 2015. Contested territorialization and biophysical expansion of oil palm plantations in Indonesia. Geoforum 64(August 2015):100-111. http://dx.doi.org/10.1016/j.geoforum.2015.06.007

Bradshaw, G. A., and M. Bekoff. 2001. Ecology and social responsibility: the re-embodiment of science. Trends in Ecology \& Evolution 16(8):460-465. http://dx.doi.org/10.1016/s0169-5347 (01)02204-2

Bronick, C. J., and R. Lal. 2005. Soil structure and management: a review. Geoderma 124(1-2):3-22. http://dx.doi.org/10.1016/j. geoderma.2004.03.005 
Brown, T. C., G. L. Peterson, R. M. Brodersen, V. Ford, and P. A. Bell. 2005. The judged seriousness of an environmental loss is a matter of what caused it. Journal of Environmental Psychology 25(1):13-21. http://dx.doi.org/10.1016/j.jenvp.2004.12.005

Bruijnzeel, L. A. 1986. Environmental impacts of (de)forestation in the humid tropics: a watershed perspective. Wallaceana 46:3-13.

Bruijnzeel, L. A. 1989. (De)forestation and dry season flow in the tropics: a closer look. Journal of Tropical Forest Science 1 (3):229-243.

Bruijnzeel, L. A. 2004. Hydrological functions of tropical forests: not seeing the soil for the trees? Agriculture, Ecosystems and Environment 104(1):185-228. http://dx.doi.org/10.1016/j.agee.2004.01.015

Bruijnzeel, L. A., and C. N. Bremmer. 1989. Highland-lowland interactions in the Ganges-Brahmaputra River Basin: a review of published literature. ICIMOD Occasional Paper no. 11. International Centre for Integrated Mountain Development, Kathmandu, Nepal.

Buschman, F. A., A. J. F. Hoitink, S. M. de Jong, P. Hoekstra, H. Hidayat, and M. G. Sassi. 2012. Suspended sediment load in the tidal zone of an Indonesian river. Hydrology and Earth System Science 16:4191-4204. http://dx.doi.org/10.5194/hess-16-4191-2012

Calder, I. R., I. R. Wright, and D. Murdiyarso. 1986. A study of evaporation from tropical rain forest-West Java. Journal of Hydrology 89(1):13-31. http://dx.doi.org/10.1016/0022-1694(86) 90139-3

Carlson, K. M., L. M. Curran, D. Ratnasari, A. M. Pittman, B. S. Soares-Filho, G. P. Asner, S. N. Trigg, D. A. Gaveau, D. Lawrence, and H. O. Rodrigues. 2012. Committed carbon emissions, deforestation, and community land conversion from oil palm plantation expansion in West Kalimantan, Indonesia. Proceedings of the National Academy of Sciences 109 (19):7559-7564. http://dx.doi.org/10.1073/pnas.1200452109

Chiti, T., E. Grieco, L. Perugini, A. Rey, and R. Valentini. 2014. Effect of the replacement of tropical forests with tree plantations on soil organic carbon levels in the Jomoro district, Ghana. Plant and Soil 375(1):47-59. http://dx.doi.org/10.1007/s11104-013-1928-1

Chokor, B. A. 2004. Perception and response to the challenge of poverty and environmental resource degradation in rural Nigeria: case study from the Niger Delta. Journal of Environmental Psychology 24(3):305-318. http://dx.doi.org/10.1016/j.jenvp.2004.08.001

Colchester, M., P. Anderson, A. Yunan Firdaus, F. Hasibuan, and S. Chao. 2011. Human rights abuses and land conflicts in the PT Asiatic Persada Concession in Jambi. Report of an independent investigation into land disputes and forced evictions in a palm oil estate. Independent Investigation of PT AP. HuMa, Sawit Watch and Forest People Programme, Moreton-in-Marsh, UK. [online] URL: http://www.forestpeoples.org/sites/fpp/files/publication/2011/11/ final-report-pt-ap-nov-2011-low-res-1.pdf

Colchester, M., and S. Chao, editors. 2011. Oil palm expansion in South East Asia: trends and implications for local communities and indigenous peoples. Sawit Watch and Forest People Programme, Moreton-in-Marsh, UK. [online] URL: http://www.forestpeoples. org/topics/palm-oil-rspo/publication/2011/oil-palm-expansion-southeast-asia-trends-and-implications-loc

Comte, I., F. Colin, J. K. Whalen, O. Grünberger, and J.-P. Calliman. 2012. Agricultural practices in oil palm plantations and their impact on hydrological changes, nutrient fluxes and water quality in Indonesia: a review. Advances in Agronomy 116:71-124. http://dx.doi.org/10.1016/B978-0-12-394277-7.00003-8

Cottet, M., H. Piégay, and G. Bornette. 2013. Does human perception of wetland aesthetics and healthiness relate to ecological functioning? Journal of Environmental Management 128:1012-1022. http://dx.doi.org/10.1016/j.jenvman.2013.06.056

de Blécourt, M., R. Brumme, J. Xu, M. D. Corre, and E. Veldkamp. 2013. Soil carbon stocks decrease following conversion of secondary forests to rubber (Hevea brasiliensis) plantations. PLOS ONE 8(7):e69357. http://dx.doi.org/10.1371/ journal.pone.0069357

Dietz, J., D. Hölscher, C. Leuschner, and Hendrayanto. 2006. Rainfall partitioning in relation to forest structure in differently managed montane forest stands in Central Sulawesi, Indonesia. Forest Ecology and Management 237(1-3):170-178. http://dx.doi. org/10.1016/j.foreco.2006.09.044

Dislich, D., A. C. Keyel, J. Salecker, Y. Kisel, K. M. Meyer, M. D. Corre, H. Faust, B. Hess, A. Knohl, H. Kreft, A. Meijide, F. Nurdiansyah, F. Otten, G. Pe'er, S. Steinebach, S. Tarigan, T. Tscharntke, M. T.lle, and K. Wiegand. 2015. Ecosystem functions of oil palm plantations: a review. EFForTS discussion paper, no. 16. GOEDOC - Dokumenten - und Publikationsserver der Georg-August-Universität Göttingen, Germany. [online] URL: http://webdoc.sub.gwdg.de/pub/mon/sfb990/dp-16.pdf

Drescher, J., K. Rembold, K. Allen, P. Beckschäfer, D. Buchori, Y. Clough, H. Faust, A. M. Fauzi, D. Gunawan, D. Hertel, B. Irawan, I. N. S. Jaya, B. Klarner, C. Kleinn, A. Knohl, M. M. Kotowska, V. Krashevska, V. Krishna, C. Leuschner, W. Lorenz, A. Meijide, D. Melati, M. Nomura, C. Pérez-Cruzado, M. Qaim, I. Z. Siregar, S. Steinebach, A. Tjoa, T. Tscharntke, B. Wick, K. Wiegand, H. Kreft, and S. Scheu. 2016. Ecological and socioeconomic functions across tropical land-use systems after rainforest conversion. Philosophical Transactions of the Royal Society B - Biological Sciences, in press.

Dykes, A. P. 1997. Rainfall interception from a lowland tropical rainforest in Brunei. Journal of Hydrology 200(1-4):260-279. http://dx.doi.org/10.1016/s0022-1694(97)00023-1

Elkaduwa, W. K. B., and R. Sakthivadivel. 1999. Use of historical data as a decision support tool in watershed management: a case study of the Upper Nilwala basin in Sri Lanka. International Water Management Institute 26.

Faust, H., S. Schwarze, B. Beckert, B. Brümmer, C. Dittrich, M. Euler, M. Gatto, B. Hauser-Schäublin, J. Hein, A. M. Holtkamp, M. Ibanez, S. Klasen, T. Kopp, V. Krishna, Y. Kunz, J. Lay, O. Mußhoff, M. Qaim, S. Steinebach, M. Vorlaufer, and M. Wollni. 2013. Assessment of socio-economic functions of tropical lowland transformation systems in Indonesia: sampling framework and methodological approach. EFForTS discussion paper, no. 1. GOEDOC - Dokumenten - und Publikationsserver 
der Georg-August-Universität Göttingen, Germany. [online] URL: http://webdoc.sub.gwdg.de/pub/mon/sfb990/2013-1.pdf

Feintrenie, L., and P. Levang. 2009. Sumatra's rubber agroforests: advent, rise and fall of a sustainable cropping system. Small-scale Forestry 8(3):323-335. http://dx.doi.org/10.1007/s11842-009-9086-2

Food and Agriculture Organization of the United Nations (FAO). 2015. FAOSTAT online statistical service. FAO, Rome, Italy. [online] URL: http://faostat.fao.org/site/567/DesktopDefault. aspx?PageID $=567$ \#ancor

Franzluebbers, J. 2002. Water infiltration and soil structure related to organic matter and its stratification with depth. Soil and Tillage Research 66:197-205. http://dx.doi.org/10.1016/S0167-1987(02) $\underline{00027-2}$

Frazão, L. A., K. Paustian, C. E. Pellegrino Cerri, and C. C. Cerri. 2013. Soil carbon stocks and changes after oil palm introduction in the Brazilian Amazon. Global Change Biology Bioenergy 5 (4):384-390. http://dx.doi.org/10.1111/j.1757-1707.2012.01196.x

Friends of the Earth, Sawit Watch, and LifeMosaic, editors. 2008. Losing ground: the human rights impacts of oil palm plantation expansion in Indonesia. Friends of the Earth, Sawit Watch, and LifeMosaic, London, UK. [online] URL: http://www.foe.co.uk/ sites/default/files/downloads/losingground.pdf

Fritsch, J. M., 1990. Les effets du défrichement de la forêt amazonienne et de la mise en culture sur l'hydrologie des petits bassins-versants en Guyane française. Dissertation, Université des Sciences et Techniques du Languedoc, Montpellier, France.

Gharibreza, M., J. K. Raj, I. Yusoff, Z. Othman, W. Z. W. M. Tahir, and M. A. Ashraf. 2013. Land use changes and soil redistribution estimation using ${ }^{137} \mathrm{Cs}$ in the tropical Bera Lake catchment, Malaysia. Soil and Tillage Research 131:1-10. http:// dx.doi.org/10.1016/j.still.2013.02.010

Granier, A. 1985. Une nouvelle méthode pour la mesure du flux de sève brute dans le tronc des arbres. Annals of Forest Science 42:193-200. http://dx.doi.org/10.1051/forest:19850204

Granier, A. 1996. Sap flow measurements using the radial flowmeter technique. INRA-Unité d'Ecophysiologie Forestiére, Champenoux, France.

Guillaume, T., M. Damris, Y. Kuzyakov. 2015. Losses of soil carbon by converting tropical forest to plantations: erosion and decomposition estimated by $\delta^{13} \mathrm{C}$. Global Change Biology 21 (9):3548-3560. http://dx.doi.org/10.1111/gcb.12907

Guillaume, T., D. Maranguit, K. Murtilaksono, Y. Kuzyakov. 2016. Sensitivity and resistance of soil fertility indicators to landuse changes: new concept and examples from conversion of Indonesian rainforest to plantations. Ecological Indicators 67:49-57, in press. http://dx.doi.org/10.1016/j.ecolind.2016.02.039

Hauser-Schäublin, B., and S. Steinebach. 2014. Harapan: a "no man's land" turned into a contested agro-industrial zone. EFForTS discussion paper, no. 4. GOEDOC - Dokumenten - und Publikationsserver der Georg-August-Universität Göttingen, Germany. [online] URL: http://webdoc.sub.gwdg.de/pub/mon/ sfb990/dp-4.pdf

Hein, J., S. Adiwibowo, C. Dittrich, Rosyani, E. Soetarto, and H. Faust. 2015. Rescaling of access and property relations in a frontier landscape: insights from Jambi, Indonesia. Professional Geographer. http://dx.doi.org/10.1080/00330124.2015.1089105

Hein, J., and H. Faust. 2014. Conservation, REDD+ and the struggle for land in Jambi, Indonesia. Pacific Geographies 41:20-25.

Hellbrück, J., and M. Fischer. 2003. Umweltpsychologie: Ein Lehrbuch. Hogrefe Verlag, Göttingen, Germany.

Irwin, A. 2001. Sociology and the environment: a critical introduction to society, nature and knowledge. Polity, Cambridge, UK.

Ittelson, W. H., editor. 1973. Environment and cognition. Seminar Press, New York, New York, USA.

Koh, L. P., and D. S. Wilcove. 2008. Is oil palm agriculture really destroying tropical biodiversity? Conservation Letters 1(2):60-64. http://dx.doi.org/10.1111/j.1755-263X.2008.00011.X

Kotowska, M. M., C. Leuschner, T. Triadiati, S. Meriem, and D. Hertel. 2015. Quantifying above' and belowground biomass carbon loss with forest conversion in tropical lowlands of Sumatra (Indonesia). Global Change Biology 21(10):3620-3634. http://dx. doi.org/10.1111/gcb.12979

Krishnaswamy, J., M. Bonell, B. Venkatesh, B. K. Purandara, K. N. Rakesh, S. Lele, M. C. Kiran, V Reddy, and S. Badiger. 2013. The groundwater recharge response and hydrologic services of tropical humid forest ecosystems to use and reforestation: support for the "infiltration-evapotranspiration trade-off hypothesis." Journal of Hydrology 498:191-209. http://dx.doi.org/10.1016/j. jhydrol.2013.06.034

Kumagai, T., G. G. Katul, T. M. Saitoh, Y. Sato, O. J. Manfroi, T. Morooka, T. Ichie, K. Kuraji, M. Suzuki, and A. Porporato. 2004. Water cycling in a Bornean tropical rain forest under current and projected precipitation scenarios. Water Resources Research 40:(1). http://dx.doi.org/10.1029/2003wr002226

Kumagai, T., T. M. Saitoh, Y. Sato, H. Takahashi, O. J. Manfroi, T. Morooka, K. Kuraji, M. Suzuki, T. Yasunari, and H. Komatsu. 2005. Annual water balance and seasonality of evapotranspiration in a Bornean tropical rainforest. Agricultural and Forest Meteorology 128:81-92. http://dx.doi.org/10.1016/j.agrformet.2004.08.006

Kumar, S. 2002. Methods for community participation. A complete guide for practitioners. Practical Action Publishing, Warwickshire, UK.

Lapeyre, R., R. Pirard, and B. Leimona. 2015. Payments for environmental services in Indonesia: What if economic signals were lost in translation? Land Use Policy 46:283-291. http://dx. doi.org/10.1016/j.landusepol.2015.03.004

Larsen R. K., N. Jiwan, A. Rompas, J. Jenito, M. Osbeck, and A. Tarigan. 2014. Towards 'hybrid accountability' in EU biofuels policy? Community grievances and competing water claims in the Central Kalimantan oil palm sector. Geoforum 54:295-305. http:// dx.doi.org/10.1016/j.geoforum.2013.09.010

Latour, B. 1993. We have never been modern. Harvard University Press, Cambridge, Massachusetts, USA.

Laumonier, Y., Y. Uryu, M. Stüwe, A. Budiman, B. Setiabudi, and O. Hadian. 2010. Eco-floristic sectors and deforestation threats in Sumatra: identifying new conservation area network 
priorities for ecosystem-based land use planning. Biodiversity and Conservation 19(4):1153-1174. http://dx.doi.org/10.1007/ s10531-010-9784-2

Ledford, H. 2015. How to solve the world's biggest problems. Nature 525(7569):308-311. http://dx.doi.org/10.1038/525308a

Lele, S. 2009. Watershed services of tropical forests: from hydrology to economic valuation to integrated analysis. Current Opinion in Environmental Sustainability 1(2):148-155. http://dx. doi.org/10.1016/j.cosust.2009.10.007

Lele, S., and A. Kurien. 2011. Interdisciplinary analysis of the environment: insights from tropical forest research. Environmental Conservation 38(2):211-233. http://dx.doi.org/10.1017/s037689291100018x

Linton, J., and J. Budds. 2014. The hydrosocial cycle: defining and mobilizing a relational-dialectical approach to water. Geoforum 57:170-180. http://dx.doi.org/10.1016/j.geoforum.2013.10.008

Mayring, P. 2002. Verfahren qualitativer Analyse. Erhebungsverfahren. Pages 65-84 in Einführung in die qualitative Sozialforschung. Eine Anleitung zu qualitativem Denken. Fifth edition. Beltz, Weinheim, Germany.

McJannet, D., P. Fitch, M. Disher, and J. Wallace. 2007. Measurements of transpiration in four tropical rainforest types of north Queensland, Australia. Hydrological Processes 21:3549-3564. http://dx.doi.org/10.1002/hyp.6576

Moore, M.-L., O. Tjornbo, E. Enfors, C. Knapp, J. Hodbod, J. A. Baggio, A. Norström, P. Olsson, and D. Biggs. 2014. Studying the complexity of change: toward an analytical framework for understanding deliberate social-ecological transformations. Ecology and Society 19(4):54. http://dx.doi.org/10.5751/ es-06966-190454

Moser, G. 1984. Water quality perception, a dynamic evaluation. Journal of Environmental Psychology 4(3):201-210. http://dx.doi. org/10.1016/s0272-4944(84)80041-9

Muñoz-Piña, C., A. Guevara, J. M. Torres, and J. Braña. 2008. Paying for the hydrological services of Mexico's forests: analysis, negotiations and results. Ecological Economics 65(4):725-736. http://dx.doi.org/10.1016/j.ecolecon.2007.07.031

Niu F., A. Röll, A. Hardanto, A. Meijide, M. Köhler, Hendrayanto, and D. Hölscher. 2015. Oil palm water use: calibration of a sap flux method and a field measurement scheme. Tree Physiology 35:563-573. http://dx.doi.org/10.1093/treephys/ tpv013

Obidzinski, K., R. Andriani, H. Komarudin, and A. Andrianto. 2012. Environmental and social impacts of oil palm plantations and their implications for biofuel production in Indonesia. Ecology and Society 17(1):25. http://dx.doi.org/10.5751/ es-04775-170125

Orenstein, E., and E. Groner. 2014. In the eye of the stakeholder: changes in perceptions of ecosystem services across an international border. Ecosystem Services 8:185-196. http://dx.doi. org/10.1016/j.ecoser.2014.04.004

Ostrom, E. 2009. A general framework for analyzing sustainability of social-ecological systems. Science 325 (5939):419-422. http://dx.doi.org/10.1126/science.1172133
Pahl-Wostl, C., G. Holtz, B. Kastens, and C. Knieper. 2010. Analyzing complex water governance regimes: the management and transition framework. Environmental Science and Policy 13:571-581. http://dx.doi.org/10.1016/j.envsci.2010.08.006

Pattanayak, S. K. 2004. Valuing watershed services: concepts and empirics from Southeast Asia. Agriculture, Ecosystems and Environment 104:171-184. http://dx.doi.org/10.1016/j.agee.2004.01.016

Pattanayak, S. K., and R. A. Kramer. 2001. Pricing ecological services: willingness to pay for drought mitigation from watershed protection in eastern Indonesia. Water Resources Research 37 (3):771-778. http://dx.doi.org/10.1029/2000wr900320

Peña Arancibia, J. L. 2013. Impacts of land use change on dry season flows across the tropics: forests as 'sponges' and 'pumps.' Dissertation, King's College, London, UK.

Poor, P. J., K. J. Boyle, L. O. Taylor, and R. Bouchard. 2001. Objective versus subjective measures of water clarity in hedonic property value models. Land Economics 77(4):482-493. http://dx. doi.org/10.2307/3146935

Reyers, B., R. Biggs, G. S. Cumming, T. Elmqvist, A. P. Hejnowicz, and S. Polasky. 2013. Getting the measure of ecosystem services: a social-ecological approach. Frontiers in Ecology and the Environment 11(5):268-273. http://dx.doi.org/10.1890/120144

Röll, A., F. Niu, A. Meijide, A. Hardanto, Hendrayanto, A. Knohl, and D. Hölscher. 2015. Transpiration in an oil palm landscape: effects of palm age. Biogeosciences 12:5619-5633. http://dx.doi.org/10.5194/bg-12-5619-2015

Sagie, H., A. Morris, Y. Rofé, D. E. Orenstein, and E. Groner. 2013. Cross-cultural perceptions of ecosystem services: a social inquiry on both sides of the Israeli-Jordanian border of the Southern Arava Valley Desert. Journal of Arid Environments 97:38-48. http://dx.doi.org/10.1016/j.jaridenv.2013.05.007

Sampaio Sieber, S., P. M. Medeiros, and U. P. Albuquerque. 2011. Local perception of environmental change in a semi-arid area of northeast Brazil: a new approach for the use of participatory methods at the level of family units. Journal of Agricultural and Environmental Ethics 24(5):511-531. http://dx.doi.org/10.1007/ $\underline{\text { s10806-010-9277-z }}$

Sandström, K. 1995. Forests and water - friends or foes? Hydrological implications of deforestation and land degradation in semi-arid Tanzania. Linköping University Electronic Press, Linköping, Sweden.

Schiffman, H. R. 1982. Sensation and perception. An integrated approach. Second edition. Wiley, New York, New York, USA.

Schnell, R., P. B. Hill, and E. Esser. 2013. Methoden der empirischen Sozialforschung. Oldenbourg Wissenschaftsverlag, München, Germany.

Steinebach, S. 2013. 'Today we occupy the plantation, tomorrow Jakarta.' Indigeneity, land and oil palm plantations in Jambi. Pages 63-81 in B. Hauser-Schäublin, editor. Adat and indigeneity in Indonesia. Culture and entitlements between heterogeneity and self-ascription. Universitätsverlag Göttingen, Germany.

Swyngedouw, E., 2004. Social power and the urbanization of water: flows of power. Oxford University Press, Oxford, UK. 
Tàbara, J. D., and I. Chabay. 2013. Coupling human information and knowledge systems with social-ecological systems change: reframing research, education, and policy for sustainability. Environmental Science and Policy 28:71-81. http://dx.doi. org/10.1016/j.envsci.2012.11.005

Tani, M., A. R. Nik, Y. Ohtani, Y. Yasuda, M. M. Sahat, B. Kasran, S. Takanashi, S. Noguchi, Z. Yusop, and T. Watanabe. 2003. Characteristics of energy exchange and surface conductance of a tropical rain forest in peninsular Malaysia. Pages 73-88 in T. Okuda, N. Manokaran, Y. Matsumoto, K. Niiyama, S. C. Thomas, and P. S. Ashton, editors. Pasoh: ecology of a lowland rain forest in Southeast Asia. Springer, Tokyo, Japan. http://dx.doi.org/10.1007/978-4-431-67008-7 6

Vicente-Serrano, S. M., S. Beguería, and J. I. López-Moreno. 2010. A multiscalar drought index sensitive to global warming: the Standardized Precipitation Evapotranspiration Index. Journal of Climate 23(7):1696-1718. http://dx.doi. org/10.1175/2009jcli2909.1

Wakker, E. 2005. Greasy palms. The social and ecological impacts of large-scale oil palm plantation development in Southeast Asia. Friends of the Earth, London, UK. [online] URL: http://www. foe.co.uk/sites/default/files/downloads/greasy_palms impacts.pdf

Wandersee, S. M., L. An, D. Lopéz-Carr, and Y. Yang. 2012. Perception and decisions in modeling coupled human and natural systems: a case study from Fanjingshan National Nature Reserve, China. Ecological Modelling 229:37-49. http://dx.doi.org/10.1016/ j.ecolmodel.2011.08.004

Wittfogel, K. A., 1957. Oriental despotism: a comparative study of total power. Yale University Press, New Haven, Connecticut, USA.

Zhou, J., B. Xia, D. S. Treves, L.-Y. Wu, T. L. Marsh, R. V. O’Neill, A. V. Palumbo, and J. M. Tiedje. 2002. Spatial and resource factors influencing high microbial diversity in soil. Applied and Environmental Microbiology 68(1):326-334. http://dx.doi.org/10.1128/ aem.68.1.326-334.2002

Zimmermann, B., A. Papritz, and H. Elsenbeer. 2010. Asymmetric response to disturbance and recovery: changes of soil permeability under forest-pasture-forest transitions. Geoderma 159(1-2):209-215. http://dx.doi.org/10.1016/j. geoderma.2010.07.013 
Appendix 1. Detailed method description.

\section{METHODOLOGY OF SOCIAL STUDY}

The research stay in Indonesia comprised a period of three months in total. An initial two week one-to-one course of Bahasa Indonesia added up on prior autodidactic learning and provided the researcher with a good basic knowledge of the Indonesian language. This knowledge as well as several meetings with our Indonesian counterparts at the Agricultural University of Bogor and the University of Jambi helped to prepare the field research and to get important insights into the Indonesian culture. Except for two expert interviews in Bogor, all interview activities were conducted in Jambi province during a period of eight weeks from May to July 2013. All interviews were conducted in Bahasa Indonesia with the help of an Indonesian research assistant who had extensive prior research experience and a very good knowledge of the English language.

Initial participants for household interviews in the village were chosen based on their relevance for the research topic, e.g. length of time lived in Bungku. Subsequent interview partners were chosen by the snowball sampling method (Schnell et al. 2013), aiming to represent the social structure of the village hamlets. Focus group discussions were conducted with groups of six independent oil palm farmers to gain insights into local attitudes and concerns regarding oil palm cultivation. All interview activities were audio-recorded and written down in form of detailed chronological protocols in English language. Data processing and analysis followed the principles of a qualitative analysis of content (after Mayring 2002). Additional personal profiles of the interview partners allowed for an empirical typification (Kluge 2000) of the participants.

\section{METHODOLOGY OF CLIMATE CHANGE ANALYSIS}

We used the Standardized Precipitation Evapotranspiration Index (SPEI), which takes into account precipitation and potential evapotranspiration, to determine drought conditions. Using the Global SPEI database (SPEIbase, Vicente-Serrano et al. 2010), which offers information about SPEI at the global scale with a 0.5 degrees resolution and monthly time resolution, we evaluated drought changes from 1900 until 2011 in Bungku area (E 103.25, S 1.25). The SPEIbase is based on monthly precipitation and potential evapotranspiration from the Climatic Research Unit of the University of East Anglia (CRUE TS 3.2 dataset).

Additionally, we analyzed air temperature and rainfall data from 1991 to 2011 from the meteorological station, property of the Indonesian meteorological service (BMKG), located at the Airport Sultan Thaha in Jambi. Rainfall was recorded daily, while temperature was manually recorded three times a day $(7,13$ and $18 \mathrm{~h})$. Daily average temperature was calculated by double counting the measurement at 7 am (to consider the lower temperatures during the night) and averaging it with the temperatures measured during the rest of the day. Daily minimum and maximum temperatures were also recorded. Data series were separated into its time components in order to detect possible changes in their trend over the period of study. 


\section{METHODOLOGY OF ENVIRONMENTAL MEASUREMENTS}

\section{Evapotranspiration}

The eddy covariance technique (Baldocchi et al. 2003) was used to measure evapotranspiration (ET) in a 12-year old oil palm plantation in Indonesia. In the oil palm plantation (S1.693 E 103.391, at approximately $25 \mathrm{~km}$ from Bungku, Fig. 1), a $22 \mathrm{~m}$ high tower, equipped with a sonic anemometer (Metek uSonic-3 Scientific, Elmshorn, Germany) to measure the three components of the wind vector, and an open path carbon dioxide and water analyzer (Li-7500A, Licor_Inc, Lincoln, USA), was running from March 2014 until December 2014. Evapotranspiration fluxes were calculated using the software EddyPro, planar-fit coordinate rotated, corrected for air density fluctuation and quality controlled (Meijide et al., in preparation). For this analysis, ET was estimated using data from three sunny days during the period of July-August 2014, using daytime (6 am-7 pm) data, in order to avoid possible measurement errors as a consequence of low turbulent conditions during nighttime hours.

\section{Transpiration}

To derive transpiration rates, we used the thermal dissipation probe (TPD, Granier, 1985, 1996) method to measure sap flux density $(S F D)$ in leaf petioles of oil palms and in the trunks of dicot trees. For oil palm, 16 TDP sensors $(1.25 \mathrm{~cm}$ length) were installed on the underside of oil palm leaf petioles on four palms of varying height per plot (see Niu et al. 2015 for details). For forest and rubber plots, two sensors were installed at breast height in the North and South, respectively, of six (rubber) or eight (forest) tree trunks per plot ( $2.5 \mathrm{~cm}$ sensor length). In the forest, we chose dominant and co-dominant individuals only, as they are expected to account for the major part of stand water use; within the dominant and co-dominant sociological classes, we evenly selected individuals of relatively larger, medium and smaller diameters (min. diameter at breast height: 10 $\mathrm{cm})$.

After sensor installation, insulative materials and aluminum foil were added to minimize temperature gradients and reflect radiation. Durable plastic foil was added for protection from rain. The sensors were connected to AM16/32 multiplexers connected to a CR1000 data logger (both Campbell Scientific Inc., Logan, USA). The signals from the sensors were recorded every $30 \mathrm{sec}$ and averaged and stored every $10 \mathrm{~min}$. In each plot, $S F D$ was measured for a minimum period of three weeks. For oil palm, the $\mathrm{mV}$-data from the logger were converted to $S F D\left(\mathrm{~g} \mathrm{~cm}^{-2}\right.$ $\mathrm{h}^{-1}$ ) with the equation by Granier (1985), but with an adjusted set of equation parameters $a$ and $b$ that was specifically derived for TDP measurements on oil palm leaf petioles (Niu et al. 2015). As for oil palm by Niu et al. (2015), the TDP method was tested against gravimetric measurements in the laboratory for rubber and forest trees. The gravimetric readings and the estimates using the original Granier equation were within the $95 \%$ confidence interval of a linear regression with a slope of 1 . Thus, the original equation parameters (Granier 1985) were used for the analysis of rubber and forest trees. 
To upscale from sap-flux point-measurements to water use rates per plant ( $\mathrm{kg} \mathrm{day}^{-1}$ ) and ultimately to stand transpiration $\left(\mathrm{mm} \mathrm{day}^{-1}\right)$, water conductive areas $\left(\mathrm{cm}^{2}\right)$ had to be established for each of the studied individuals and stands. For oil palm leaf petioles at the location of sensor installation, we used a linear regression between leaf baseline length and leaf conductive area, which was derived by Niu et al. (2015) for oil palms in the same study region based on laboratory staining experiments. To derive water conductive areas for dicot trees in forest and rubber plots, we measured the radial patterns of $S F D$ with increasing depth $(d, \mathrm{~cm})$ into the xylem (0-8 cm, $1 \mathrm{~cm}$ resolution) with heat field deformation sensors (HFD, Nadezhdina, 2012, sensors from ICT International, Armidale, Australia) in 10 individuals per land use type. The measurements were conducted in parallel to TDP measurements $(0-2.5 \mathrm{~cm}$ depth) on these individuals; HFD sensors were installed in between TDP sensors (North and South), i.e. in the West, at a similar height on the tree. The radial SFD patterns obtained by the HFD measurements were normalized to a depth of $1.25 \mathrm{~cm}$ (center of TDP sensors) to allow for an extrapolation of the single-point TDP measurements in the outer xylem $(0-2.5 \mathrm{~cm})$ to whole-tree water use rates (following Oishi et al. 2008). To subsequently upscale to stand-scale transpiration rates inventory data were used.

The sap flux measurements were conducted between March 2013 and April 2014. As most measurements could not be conducted in parallel for logistical reasons, we used the respective averages of the three most sunny and dry days within each measurement period (min. 3 weeks) for the analysis of the spatial variability in transpiration rates between plots, as to minimize dayto-day variability induced by weather.

\section{Soil characteristics and erosion}

Soil samples were collected per horizon in one soil pit on each plot. The subsoil under plantations was not affected by enhanced decomposition processes after forest conversion (Guillaume et al. 2015). Carbon content and $\mathrm{C} / \mathrm{N}$ ratio below the Ah horizons were similar under forest and plantations. Therefore, we assessed erosion by assuming $\mathrm{C}$ isotopic composition $\left(\delta^{13} \mathrm{C}\right.$ values) in the plantation subsoil was similar to the values in the forest subsoil prior to conversion. Consequently, when an identical subsoil depth has a higher $\delta^{13} \mathrm{C}$ in the plantation than the forest, we suggest that this layer experienced a vertical shift towards the soil surface after erosional loss of the upper layer.

A power function describing the increase of $\delta^{13} \mathrm{C}$ with depth under forest was fitted in Statistica 10 using Equation A1.1.

$$
\delta^{13} \mathrm{C}_{\mathrm{d}}=\delta^{13} \mathrm{C}_{\mathrm{Ah}} \mathrm{d}^{1}
$$

where $\mathrm{C}(\mathrm{d}), \delta^{13} \mathrm{C}(\mathrm{d}), \mathrm{C}(\mathrm{Ah})$ and $\delta^{13} \mathrm{C}(\mathrm{Ah})$ are the $\mathrm{C}$ content and the $\delta^{13} \mathrm{C}$ value estimated for the depth $d$ and measured in the Ah horizon, respectively, $d$ the depth in $\mathrm{cm}$ and 1 the fitted parameters of the function. Regressions were fitted using all samples below the Ah horizons in the four forest replicate plots. 
Erosion was calculated using the power function describing the distribution of $\delta^{13} \mathrm{C}$ with soil depth in the forest plots. Assuming that the shift in $\delta^{13} \mathrm{C}$ in the plantation subsoil resulted from shift in the depth due to the erosion after conversion, we calculated the original depth before erosion for all samples under plantations by modifying Equation A1.2:

$$
\mathrm{d}_{b}=10^{\frac{\log _{10}\left(\delta 13 C_{d} / \delta 13 C_{A h}\right)}{-l}}
$$

where $d_{b}$ is the estimated depth before the conversion to plantation, $\delta^{13} \mathrm{C}_{\mathrm{d}}$ is the $\delta^{13} \mathrm{C}$ values of the samples under plantation at depth $d, \delta^{13} \mathrm{C}_{\mathrm{Ah}}$ is the mean $\delta^{13} \mathrm{C}$ values of the $\mathrm{Ah}$ horizons under forest, and $l$ is the parameters estimated for the soils under forest. The difference between the estimated depth before conversion $\left(d_{b}\right)$ and depth at which the sample was collected $(d)$ corresponds to erosion. The erosion for one plantation plot was calculated by averaging the erosion estimated for each sample collected in the plot. We excluded Ah horizons and samples deeper than $77 \mathrm{~cm}$, which corresponds to the deepest sample under forest.

\section{Microclimatic effects of land use change}

A $2.5 \mathrm{~m}$ aluminum mast was placed in the center of the plots. A thermo-hygrometer (Galltec Mella, Bondorf, Germany) was installed at $2 \mathrm{~m}$ height in the mast and a soil temperature and moisture sensor (Trime-Pico 32, IMKO, Ettlingen, Germany) was placed $0.3 \mathrm{~m}$ under the soil surface. Both sensors were connected to a data logger (LogTrans16-GPRS, UIT, Dresden, Germany). Data were recorded every hour, for 16 months from June 2013 on.

\section{Micro-catchment related measurements}

\section{General catchment characteristics}

Within two small catchments partly encompassing the oil palm and rubber plantations (plots HO1-4, HR1-4, Fig. 1), we recorded streamflow and measured rainfall interception for four months. One catchment (extension of 14.2 ha) was dominated by $10-14$ year-old oil palm plantations ( $90 \%$ of the area). The other catchment ( 4.9 ha) consisted of different rubber stands: eight year-old (19\% of the area) and 30 year-old (56\% of the area) mono-culture rubber plantations and jungle rubber ( $25 \%$ of the area), a mix of rubber trees and naturally established dicot tree species. We selected a two week period (7 to 20 Nov 2013) of the recorded hydrographs encompassing both dry and rainy conditions. Rainfall interception of the oil palm and rubber monocultures in the respective catchments was assessed by measuring throughfall and stemflow, and subtracting them from incident rainfall.

\section{Precipitation}

We measured incident rainfall with three ombrometers $\left(154 \mathrm{~cm}^{2}\right.$ collection area each) in open areas no more than $100 \mathrm{~m}$ from the respective catchments. Data were recorded manually at 6 am 
every day. We observed 30 rainfall events during our measurement period from November 2012 to February 2013, ranging from light to heavy rain (see Fig. A1.1).

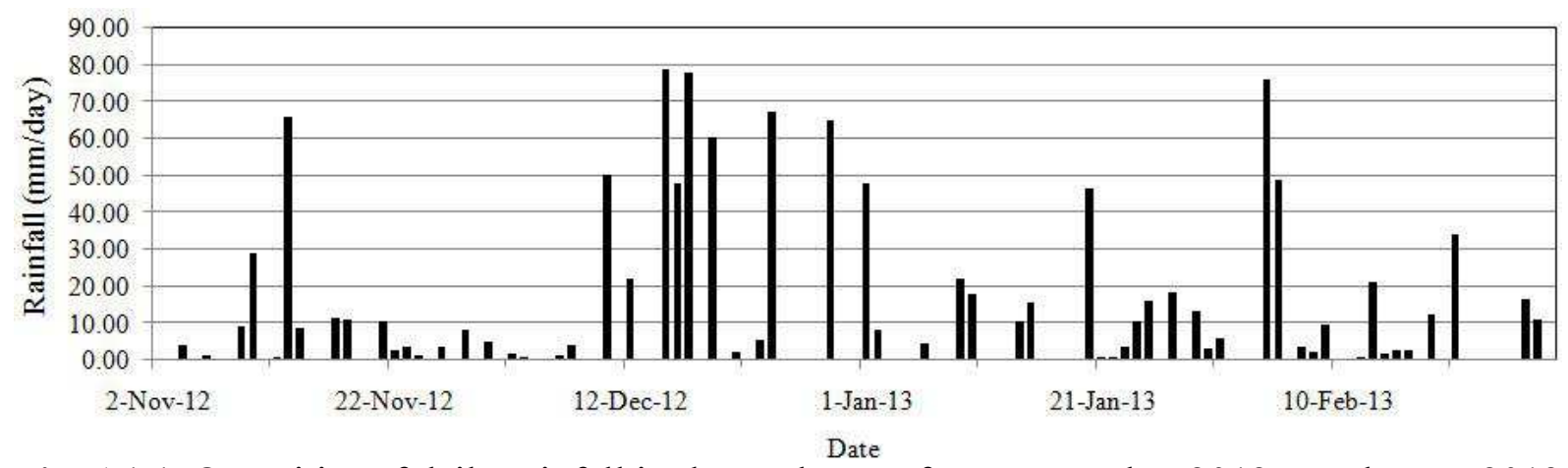

Fig. A1.1. Quantities of daily rainfall in the study area from November 2012 to February 2013.

\section{Streamflow}

The two catchments were instrumented with a rectangular weir. The water levels in the weirs were continuously recorded using a HOBO Water Level Data Logger (Type U20-001-01, Onset, Bourne, MA, USA). Recorded water levels were converted to discharge units using Equation A1.3.

$$
Q_{\mathrm{r}}=0.57 \mathrm{H}^{1.44}(\mathrm{~A} 1.3)
$$

Where $Q_{\mathrm{r}}$ is rectangular weir discharge $\left(1 \mathrm{~s}^{-1}\right)$ and $\mathrm{H}$ is the water level in the weir $(\mathrm{cm})$.

\section{Throughfall}

Throughfall samplers were made of 10-liter-canisters with funnels attached to the top for water collection. In oil palm plantations, the samplers were installed in diagonal patterns between adjacent palms. In total, the measurements were carried out in eight diagonal lines, where four lines represent $2 \mathrm{~m}$ and $4 \mathrm{~m}$ distance from respective trunks and the remaining four lines represent $1 \mathrm{~m}$ and $3 \mathrm{~m}$ distance from the trunk. Combined, the throughfall data thus had a resolution of $1 \mathrm{~m}$. In rubber plantations, throughfall samplers were placed between adjacent rubber trees at distances of $1 \mathrm{~m}$ and $2 \mathrm{~m}$ from the trunk. Recordings were taken daily between November 2012 and February 2013.

\section{Stemflow}

Stemflow was measured by circling and sticking semicircle-shaped metal sheets from the top to the bottom of the trunk. The circling ended $50 \mathrm{~cm}$ above ground to allow for the placement of water collectors beneath it. Stemflow collectors were installed on four oil palm and six rubber 
trunks, respectively. The measurements were conducted between November 2012 and February 2013.

\section{Interception}

Interception was calculated by subtracting stemflow and throughfall from incident rainfall at the plot scale. Given that interception is based on the area of palm or tree canopy cover, stemflow data were normalized with canopy area before subtraction. Throughfall values on the canopy level were obtained by averaging measurements at various distances from the trunks of several individuals.

\section{LITERATURE CITED IN APPENDIX}

Baldocchi, D. 2003. Assessing the eddy covariance technique for evaluating carbon dioxide exchange rates of ecosystems: past, present and future. Global Change Biology 9:479-492.

Bush, S. E., K. R. Hultine, J. S. Sperry, J. R. Ehleringer. 2010. Calibration of thermal dissipation sap flow probes for ring- and diffuse-porous trees. Tree Physiology 30:1545-1554.

Granier, A. 1985. Une nouvelle méthode pour la mesure du flux de sève brute dans le tronc des arbres. Annals of Forest Science 42:193-200.

Granier, A. 1996. Sap flow measurements using the radial flowmeter technique. INRA-Unité d'Ecophysiologie Forestiére, Champenoux, pp 1-9.

Guillaume, T., M. Damris, Y. Kuzyakov. 2015. Losses of soil carbon by converting tropical forest to plantations: erosion and decomposition estimated by $\delta 13 \mathrm{C}$. Global Change Biology, in press: DOI: $10.1111 / \mathrm{gcb} .12907$.

Kluge, S. 2000. Empirisch begründete Typenbildung in der qualitativen Sozialforschung. Forum Qualitative Sozialforschung 1 (1). [online] URL: http://www.qualitativeresearch.net/index.php/fqs/article/viewFile/1124/2498 (last accessed 02/12/2014).

Kumar, S. 2002. Methods for community participation. A complete guide for practitioners. London. Practical Action Publishing. Warwickshire, UK: pp. 71-78, 118-127.

Lu, P., L. Urban, and P. Zhao. 2004. Granier's thermal dissipation probe (TDP) method for measuring sap flow in trees: theory and practice. Acta Botanica Sinica 46, no. 6:631-646.

Mayring, P. 2002. Einführung in die qualitative Sozialforschung. Eine Anleitung zu qualitativem Denken. Beltz, Weinheim, Germany, 5th edition: pp. 66-84, 144-120.

Meinzer, F. C., B. J. Bond, J. M. Warren, and D. R. Woodruff. 2005. Does water transport scale universally with tree size? Functional Ecology 19:558-565. 
Nadezhdina, N., M. W. Vandegehuchte, and K. Steppe. 2012. Sap flux density measurements based on the heat field deformation method. Trees 26 (5):1439-1448.

Niu F., A. Röll, A. Hardanto, A. Meijide, M. Köhler, Hendrayanto, and D. Hölscher. 2015. Oil palm water use: calibration of a sap flux method and a field measurement scheme. Tree Physiology, in press: DOI: 10.1093/treephys/tpv013.

Oishi, A. C., R. Oren, and P. C. Stoy. 2008. Estimating components of forest evapotranspiration: a footprint approach for scaling sap flux measurements. Agricultural and Forest Meteorology 148:1719-1732.

Renninger, H. J., N. Phillips, and G. D. Salvucci. 2010. Wet- vs. dry-season transpiration in an Amazonian rain forest palm Iriartea deltoidea. Biotropica 42:470-478.

Schnell, R., P. B. Hill, and E. Esser. 2013. Methoden der empirischen Sozialforschung. Oldenbourg Wissenschaftsverlag, München, Germany: p. 292.

Sperling, O., O. Shapira, S. Cohen, E. Tripler, A. Schwartz, and N. Lazarovitch. 2012. Estimating sap flux densities in date palm trees using the heat dissipation method and weighing lysimeters. Tree Physiology: tps070.

Sun, H., D. P. Aubrey, and R. O. Teskey. 2012. A simple calibration improved the accuracy of the thermal dissipation technique for sap flow measurements in juvenile trees of six species. Trees 26, no. 2:631-640.

Vicente-Serrano, S.M., S. Beguería, and J. I. López-Moreno. 2010. A multiscalar drought index sensitive to global warming: the Standardized Precipitation Evapotranspiration Index. Journal of Climate 23 (7):1696-1718. 